\title{
A revision of the bee genus Nomada in Argentina (Hymenoptera, Apidae, Nomadinae)
}

\author{
Arturo ROIG ALSINA \\ Museo Argentino de Ciencias Naturales «Bernardino Rivadavia,» Av. Angel Gallardo 470, \\ 1405 Buenos Aires, Argentina.
}

\begin{abstract}
A revision of the bee genus Nomada Scopoli in Argentina is presented. Nine species are recognized in this region, five of which are described as new: N. mesopotamica, N. longula, N. chacoana, N. missionica, and N. turrigera. Lectotypes are designated for N. pampicola Holmberg, 1886, and N. costalis Brèthes, 1909. A new name, $N$. holmbergiana, is proposed for Hypochrotaenia parvula Holmberg, 1886, preoccupied in Nomada, and a neotype is designated for $H$. parvula Holmberg. A key to the species, descriptions, distributional data, and illustrations are provided.
\end{abstract}

Key words: Cleptoparasitic bees, Nomadini, Argentina, new species.

Resumen: Revisión de las abejas del género Nomada en la Argentina (Hymenoptera, Apidae, Nomadinae). Se presenta una revisión de las abejas del género Nomada Scopoli en la Argentina. Se reconocen nueve especies en esta región, de las cuales cinco se describen como nuevas: $N$. mesopotamica, $N$. longula, $N$. chacoana, N. missionica y N. turrigera. Se designan lectotipos para N. pampicola Holmberg, 1886, y N. costalis Brèthes, 1909. Se propone un nuevo nombre, N. holmbergiana, para Hypochrotaenia parvula Holmberg, 1886, preocupado en Nomada, y se designa un neotipo para H. parvula Holmberg. Se presenta una clave para las especies, descipciones, datos de distribución e ilustraciones.

Palabras clave: Abejas cleptoparásitas, Nomadini, Argentina, nuevas especies.

\section{INTRODUCTION}

The species of Nomada Scopoli belong in the subfamily Nomadinae, a large and diverse group of bees all of which are cleptoparasites (Michener, 2007). The genus Nomada is by far the most speciose within the subfamily, with over 800 described species (Alexander \& Schwarz, 1994). These bees occur in all the continents, but are particularly abundant in the northern hemisphere. The South American fauna is rather poor in species, and a single group is represented of the seventeen species-groups that Alexander (1994) recognized for the world fauna. This group has been variously treated in the past, as the subgenus or genus Hypochrotaenia Holmberg (Michener, 1954; Snelling, 1986), as the modesta species-group (Alexander, 1991), or as the vegana species-group (Alexander, 1994). There is evidence that it is a monophyletic group (Alexander, 1994). The systematics of Nomada in South America has received little attention and it is in a poor state of knowledge, in spite of the reduced number of species present in the region. A recent contribution of Schwarz \& Gusenleitner (2004) has begun to remedy this situation with a detailed redescription of critical specimens. The present contribution presents a revision of the nine species that occur in Argentina, five of which are described as new.
Species of Nomada have been associated with hosts in several families of bees, but the majority of them belong to the genus Andrena Fabricius, an association that may be ancestral for the genus (Alexander, 1991). The information on host association for the Neotropical species is extremely scanty, since hosts are only known for three species in the Caribbean, which parasitize species of Exomalopsis Spinola and Agapostemon Guérin (Alexander, 1991), and for one unidentified species of Nomada from Brazil, which parasitizes Exomalopsis auropilosa Spinola (Rozen, 1997). The life histories of Argentinean species are yet to be studied.

Species of Nomada may be confused with species of the related tribe Brachynomadini and allies, which have a similar habitus and size. They can be easily distinguished because species of Nomada in South America always have yellow integumental markings, while brachynomadines, also patterned with red and black, completely lack yellow markings, having instead bands and patches of white to yellowish pubescence.

\section{MATERIAL AND METHODS}

Specimens studied are deposited in the following institutions: Instituto y Fundación Miguel 
Lillo, Tucumán (IFML); Museo Argentino de Ciencias Naturales «Bernardino Rivadavia,» Buenos Aires (MACN); Museo de La Plata, La Plata (MLP); United States National Museum of Natural History, Washington D.C. (USNM); Zoologische Staatssammlung, München (ZSM). Acronyms are used to indicate depositories of the specimens.

The following abbreviations are used: AOD, antennocular distance; IAD, interantennal distance; POD, post-ocellar distance; OOD, ocellocular distance; $\mathrm{CA}$, distance from anterior margin of clypeus to lower tangent of antennal sockets; AMO, distance from lower tangent of antennal sockets to lower tangent of median ocellus. The maximum diameter of the median ocellus (MOD) is used as a reference to express the length of the pubescence and other structures. The metasomal terga (T) and sterna (S) are identified with Arabic numerals. The sex of the specimens is indicated by $\mathrm{F}$, female, and $\mathrm{M}$, male.

\section{SYSTEMATICS}

All the Neotropical species of Nomada are classified in the subgenus Hypochrotaenia Holmberg, the vegana species-group of Alexander (1994). Snelling (1986) defined Hypochrotaenia, which he treated at the genus level, by the following characters, not taking into account those that he mentioned as variable: gonocoxite with a digitiform inner dorsal lobe, forecoxa with an apical tooth or spine, paraocular carina absent, mandible without preapical tooth, first flagelar segment at least as long as second, lack of specialized subgenital brush, gonostylus without specialized groups of setae, and anterior margin of the pronotum subangulate to angulate laterally. The first three characters are synapomorphies of the monophyletic vegana species-group in the cladistic analysis of Alexander (1994), while the last character unites the vegana with the roberjeotiana species-group (the last one equivalent to the subgenus Nomadita Mocsáry).

The problems of recognizing subgenera within Nomada were stated by Alexander (1994), who refrained from using them and divided the genus in 17 species-groups, two of them remaining as paraphyletic. It would be desirable to have a subgeneric classification of Nomada, but this seems not feasible until the taxonomy of its species and the phylogenetic relationships are better understood. In any case, I have found useful to recognize species-groups among the South American species, which are not equivalent to Alexander's species-groups, but all fall within his vegana group.

\section{Species groups}

There are four distinctive species-groups present in the Argentinean fauna. Two of them agree with the delimitation proposed by Snelling (1986) respectively for Hypochrotaenia s. str. and Micronomada Cockerell \& Atkins. The other two are very distinctive small groups, and may prove to be derivatives from wihtin the former two. A phylogenetic analysis of the species of Hypochrotaenia (the vegana group of Alexander, 1994) is badly needed, but is beyond the scope of this contribution.

Nomada bonaerensis Holmberg, N. mesopotamica n. sp., N. costalis Brèthes, and N. holmbergiana $n$. $n$. belong in the group that Snelling (1986) characterized as Hypocrotaenia in a strict sense. It is distinguished by the dorsal surface of the hind tibia with coarse, dark spiniform setae arising from the spicules, and by the hind coxa laterally expanded, with the dorsal outer margin keeled or not. The forecoxa bears an apical spine or at least a tooth-like projection. The forewing is darker along the costal margin, or it is entirely infuscate with a clear preapical spot. Usually the males have the sculpture of the integument stronger than that of the females (Figs. 34-35). This group includes the largest number of Neotropical species of Nomada.

Nomada pampicola Holmberg was included by Snelling (1986) in Micronomada, due to the rounded hind coxa, and the feeble setae present on the dorsal margin of the hind tibia. The pronotal collar has rounded lateral angles, and the forecoxa bears an apical spine. It is the only species present in Argentina of this group, which has its maximal diversity in North America.

Nomada longula $n$. sp. belongs in a group characterized by their wings with an amber membrane and yellowish veins and pterostigma. All included species have two submarginal cells due to the loss of the second abscissa of vein Rs. The face is broad, squarish, with the antennal sockets well above the middle of the face, the swollen area between the antennal sockets nearly reaching the middle ocellus, and the upper paraocular areas also swollen. The body is elongate and the color patterns remind those of some social vespids. The epithets coined by Ducke (1908, Nomada polybioides) and by Cockerell (1916, Polybiapis mimus) refer to this fact. According to Snelling (1986) N. abnormis Ducke is related to polybioides and mimus. Schwarz \& Gusenleitner (2004) have carefully redescribed mimus. In this group, like in bonaerensis and allies, the dorsal surface of the hind tibia has coarse, dark spiniform setae arising from the spicules and the hind coxa is laterally expanded, usually with the dorsal outer margin keeled. 
Nomada missionica n. sp. and N. turrigera $n$. $s p$. belong, together with $N$. infequens Smith, in a very distinctive group. The forewing is moderately infuscate, darker on the apical margin, not along the costal margin, the vestiture is sparse and short, the scape is short, obconical, not flattened as in the other species, the scutum is strongly, coarsely punctured, there is almost no sexual dimorphism in the punctation of the integument, the scutellum is elevated, with the dorsal surface flat but strongly punctured, with a projecting posterior margin, and separated from the scutum by a deep transverse furrow, the hind coxa is rounded, the hind tibia on the dorsal surface has whitish setae arising from the spicules, the propodeal supraspiracular ridge is well developed, and the pygidial plate of the male is apically notched. These species have the marginal cell narrowed beyond the vein $2^{\text {nd }} \mathrm{r}-\mathrm{m}$ and pointed on the wing margin, missionica and turrigera more distinctly so. According to Ducke's original description (1910), and subsequent notes (1912), N. multicolor most probably belongs in this group. He mentioned for this species the rounded hind coxa, the elevated scutellum, the short and sparse vestiture, the narrowed marginal cell pointed on the wing margin, and the forewing infuscate apically. Nomada chacoana $n$. $s p$. is tentatively associated with infrequens and allies. It agrees with this group in the rounded hind coxa, elevated scutellum separated from the scutum by a deep, transverse furrow, a well-developed propodeal supraspiracular ridge, and a notched pygidial plate of the male. It differs in other characteristics, such as the forewing infuscate along the costal margin, and the strong procoxal spine.

\section{KEY TO SPECIES OF NOMADA IN ARGENTINA}

\section{(Females of N. longula and N. turrigera not known)}

1.- Wings membrane amber, with yellowish veins. Malar space of male above posterior articulation of mandible nearly one third as long as basal width of mandible. longula

-- Wings infuscate along anterior margin, or apically, or both; veins brown to dark brown. Malar space of males above posterior articulation of mandible at most one fifth as long as basal width of mandible; posterior articulation of mandible nearly touching margin of eye in females.

2.- Face of female slightly depressed, that of male flat. Pronotal collar in upper view with anterior margin straight (Fig. 23) pampicola

-- Face of both sexes convex. Pronotal collar in upper view with anterior margin slightly to distinctly concave (Figs. 15-22).

3.- Hind coxa not expanded laterally, dorsal outer margin broadly rounded. Hind tibia of female on dorsal surface with slender, whitish setae arising from spicules (Figs. 1-2). Pygidial plate of male with notched apex (Figs. 12-14).

-- Hind coxa expanded laterally, with dorsal outer margin frequently keeled. Hind tibia of female on dorsal surface with coarse, dark spiniform setae arising from spicules (Fig. 3). Pygidial plate of male with rounded to truncate apex (Figs. 6-11)

4.- Scutellum at union of dorsal horizontal surface and posterior vertical surface, narrowly rounded, punctures of dorsal surface not coalescent. Metanotum nearly flat. Forecoxa with apical spine. chacoana

- Scutellum at union of dorsal horizontal surface and posterior vertical surface, sharply, irregularly carinate due to coarse, coalescent punctures. Metanotum convex, protruding. Forecoxa without apical spine.

5.- Mesopleuron with impunctate band along meso-metapleural suture. Pronotal lobe shiny, with few inconspicuous punctures. Largest punctures on mesopleuron nearly as large as MOD. Male antenna with pedicel clearly visible. missionica

-- Mesopleuron punctate throughout. Pronotal lobe punctured, with punctures as large as those around ocelli. Largest punctures on mesopleuron at most half as large as MOD. Male antenna with most of pedicel hidden within apex of scape. turrigera 
6.- Pronotal collar in upper view with anterior margin distinctly concave and lateral angle carinate, angulose (Figs. 16-17). Hypostomal area of female with dense, plumose hairs. .......... 7

- Pronotal collar in upper view with anterior margin weakly concave and lateral angle rounded (Figs. 15, 18). Hypostomal area of female with slender, simple hairs. ... 8

7.- Hind coxa broadly expanded, with lateral margin keeled, angulose in dorsal (or ventral) view (Fig. 4). Forewing with three submarginal cells. Forecoxa with apical tooth-like projection. costalis

-- Hind coxa moderately expanded, with lateral margin narrowly rounded, not angulose in dorsal (or ventral) view (Fig. 5). Forewing with two submarginal cells. Forecoxa with long apical spine. holmbergiana

8.- Forewing infuscate along anterior margin; pterostigma brown like other wing veins, sometimes paler, but always clothed with dark hairs. Scutum of female with extremely fine punctures, 0.2-0.4 times as large as those on posterior part of scutellum. .................. bonaerensis

.- Forewing infuscate, except preapical hyaline spot at level of veins second $\mathrm{r}-\mathrm{m}$ and second $\mathrm{m}$ $\mathrm{cu}$; pterostigma yellowish, clothed with yellowish hairs, contrasting with dark venation. Scutum of female with punctures of similar size to those on posterior part of scutellum, although some finer interspersed punctures may be present. Mesopotamica

\section{Nomada bonaerensis Holmberg (Figs. 6, 15, 24, 28)}

Nomada bonaerensis Holmberg, 1886: 238-239 (male, Arrecifes, Buenos Aires, col. M. Oliveira César, 1882; male, alrededores de Buenos Aires, col. E.L. Holmberg, XII-1874; types lost). Dalla Torre, 1896: 340. Schrottky, 1903: 184. Alexander \& Schwarz, 1994: 241. Schwarz \& Gusenleitner, 2004: 1428. Moure \& Melo, 2007: 595.

This species was not properly recognized after its original description. Holmberg (1986) indicated that his $N$. bonaerensis, based on males, could be the other sex of $N$. pampicola Holmberg, based on females only. Schrottky (1913), in his list of the Hymenoptera of Argentina, included only $N$. pampicola, probably considering $N$. bonaerensis as a junior synonym. No specimens besides the types have been referred to $N$. bonaerensis to date, although Schwarz and Gusenleitner (2004) make a compartive comment, considering $N$. bonaerensis a valid species related to $N$. xanthopus Friese, $N$. bicellularis Ducke, and N. costalis Brèthes. In spite of the loss of the types, the detailed description provided by Holmberg (1886) allows the identification of the species with certainty.

The punctation of the integument in species of Nomada is frequently different in both sexes, being that of the male stronger than that of the female. This difference is maximal in $N$. bonaerensis, the females of which have a nearly impunctate scutum, while the males have strong punctures (Fig. 24). This strong sexual dimorphism is also seen in $N$. limata Cresson, $N$. nigrescens Friese, and $N$. confusa Schwarz and
Gusenleitner (Schwarz \& Gusenleitner, 2004). Among species present in Argentina this difference is also seen in N. costalis (Figs. 34-35), $N$. mesopotamica, and N. holmbergiana, although less pronounced in the last species. At the other extreme, there is almost no difference in punctation between females and males of $N$. missionica and N. chacoana (Figs. 37-38).

Diagnosis. This species is characterized by the polished, nearly impunctate, flat scutum of the female, while the scutum of the male is strongly punctate. It is the most hirsute among Argentinean species, with hairs on the mesopleuron and the metasoma as long as three times the mid-ocellar diameter. Both sexes lack the mat of short, plumose hairs on the hypostomal area seen in the other studied species, except females of $N$. mesopotamica.

Female. Length: 5.6-8.2 mm; length of forewing 5.2-6.8 mm. Color. Black, with following parts yellow or reddish: clypeus with central yellow area surrounded by reddish; paraocular area with yellow band from lateral margin of clypeus to eye margin and then along eye margin, slightly surpassing upper level of antennal socket, such a band surrounded by reddish; in some specimens most of face from upper level of sockets to apex of clypeus reddish, with yellow restricted to paraocular band; mandible reddish with basal yellow spot; posterior margin of eye with upper yellow spot; scape, pedicel and first flagellomere yellowish brown, contrasting with dark brown of rest of flagellum. Pronotal collar reddish, ex- 

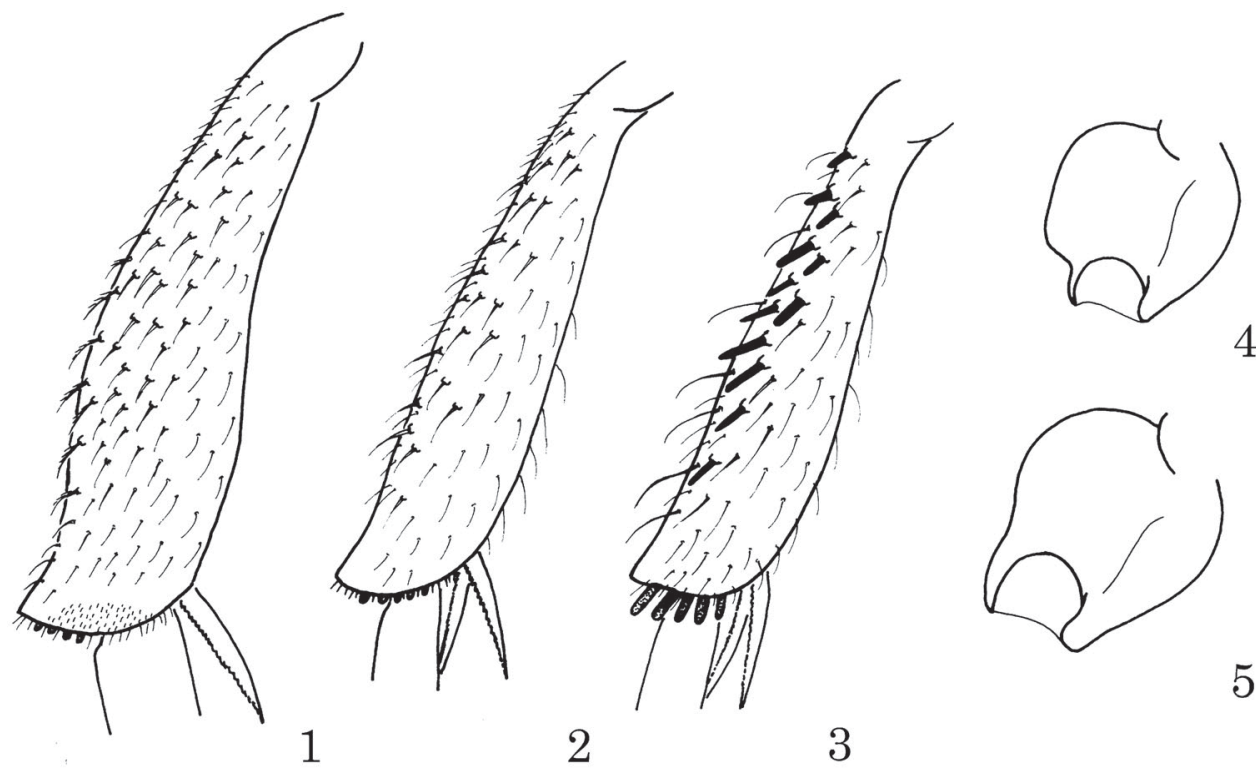

\section{4}
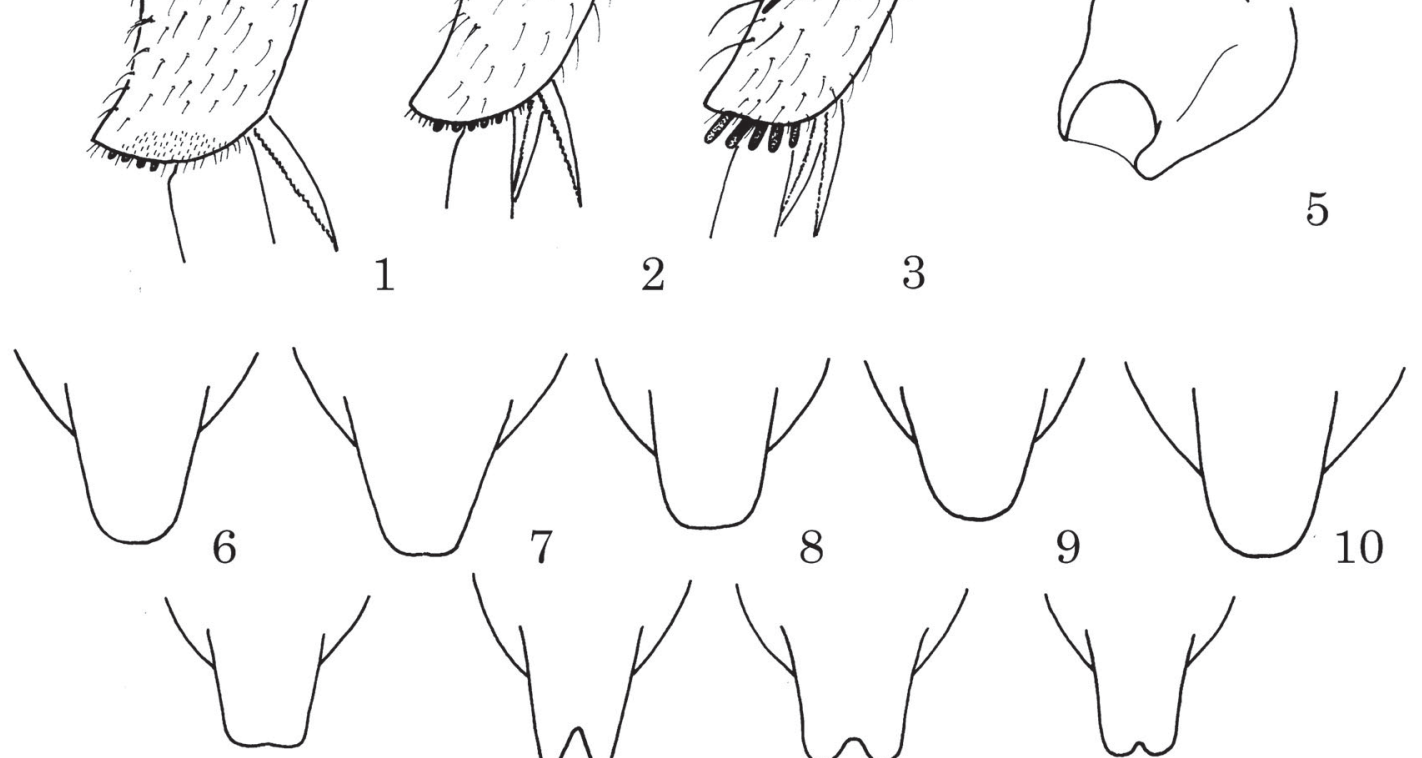

11
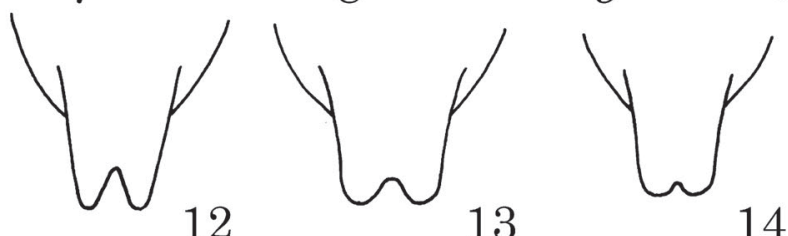

13

14

Figs. 1-14. 1-3, hind tibia of female; 1, missionica; 2, chacoana; 3, mesopotamica. 4-5, hind coxa of female; 4, costalis; 5, holmbergiana. 6-14, seventh metasomal tergum of male showing pygidial plate; 6 , bonaerensis; 7 , mesopotamica; 8, costalis; 9 holmbergiana; 10 , pampicola $; 11$, longula $; 12$, chacoana $; 13$, turrigera $; 14$, missionica .

cept median portion yellow; pronotal lobes and sometimes lateral portions of pronotum reddish. Tegula reddish brown. Mesopleuron without yellow markings, sometimes with posterior reddish area. Scutellum reddish with median transverse yellow band and yellow spot on axilla; metanotum with yellow band. Legs reddish brown, front and middle pairs paler; spurs yellowish; middle and hind coxae sometimes with narrow lateral yellow stripe. T1-T2 with yellow preapical bands, that on T1 expanded laterally; T4 in some specimens with narrow, poorly defined yellow band medially; T5 frequently with yellowish lateral spot. Sterna black. Forewing with strongly infuscate band along anterior margin, occupying costal, radial, first cubital, first medial, first submarginal, second submarginal, and marginal cells to wing apex; hind wing evenly moderately infuscate; veins and pterostigma dark brown. Sculpture. Clypeus, supraclypeal, and paraocular areas irregularly punctate, with interspersed small and moderate, shallow punctures, separated by one puncture diameter or more; integument between punctures shiny. Punctures above level of antennal sockets deep, dense, separated by less than half puncture diameter. Punctures of scutum with diameter of 5-10 $\mu$; scutum polished, flat, with median longitudinal furrow and parapsidal furrows weakly marked, indicated mainly by line of unevenly spaced small punctures; margins of scutum with small, shallow, sparse punctures; disc of scutum with few scattered punctures. Scutellum with dorsal surface flat, with sparse punctation, similar to that of paraocular area; posterior surface rounded in profile, with stronger punctation and shallow 
longitudinal median depression. Mesopleuron with deep punctures separated 0.3-1 puncture diameter. Metapostnotum roughened, microstriate. $\mathrm{T} 1$ finely punctured; base of $\mathrm{T} 2$ with small, close punctures; depressed apical band of $\mathrm{T} 2$ with irregular series of fine punctures bearing long hairs. Vestiture. Long, erect hairs with curved apices on most of body; hairs on scutum 1.0-2.5 times MOD, hairs on mesopleuron 1.5-3.0 times MOD; apex of T2 and T3-T5 covered with long hairs, those at sides of T2-T4 up to 3 times MOD. Hypostomal area with slender, simple hairs. Structure. Clypeus, supraclypeal area, and paraocular areas forming even, moderately convex surface; epistomal and subantenal sutures not set in furrows. Proportion POD:OOD, 1:1.3; IAD:AOD, 1:1. Antennal sockets above middle of face, proportion CA:AMO, 1.7:1. Scape 2.7 times as long as its apical width, compressed, with plical surface flattened, curved. Labrum rectangular, 1.8 times as wide as long, with three preapical denticles, laterally carinate. Prontal collar in dorsal view with anterior margin weakly concave; lateral angle rounded; collar width subequal to intertegular span (1:1.02-1.05). Dorsal surface of scutellum continuous with surface of scutum. Upper end of metapleuron transversely keeled. Supraspiracular ridge moderately developed above propodeal spiracle. Forecoxa with short apical spine. Hind and mid tibiae on dorsal surface with coarse, dark spiniform setae arising from spicules. Apex of hind tibia with 4 large spiniform setae. Hind coxa expanded laterally, with dorsal outer margin keeled. Forewing with three submarginal cells. Apex of marginal cell rounded.

Male. Length: 5.5-9.0 mm; length of forewing 5.6-6.6 mm. Color. Black, with following parts yellow: triangular spot on clypeus, spot on base of mandible and lower part of malar area, paraocular band (similar to that of female, but narrower and not surrounded by reddish), upper spot on posterior margin of eye, band on middle of pronotal collar, transverse bands on scutellum and metanotum, preapical bands on T1-T2 always present. T3-T6 variable, black or with narrow preapical yellow bands, sometimes irregularly interrupted. Spot on clypeus and band on scutellum reddish in some specimens. Lateral angle of collar and pronotal lobe reddish. Antenna, legs, and wings as those of female. Sculpture. Coarser than that of female. Clypeus and lower part of paraocular areas with deep punctures separated by half puncture diameter or less; supraclypeal area with punctures larger, separated by $0.5-1$ puncture diameter. Scutum strongly punctured, punctures deep, with diam- eter of $25-40 \mu$, separated by $0.2-0.3$ puncture diameter; median longitudinal furrow weakly marked; parapsidal furrows inapparent due to punctation, in some specimens between median longitudinal line and parapsidal lines with few impunctate interspaces as large as 1-1.5 puncture diameters. Mesopleuron with deep punctures separated by 0.2-0.3 puncture diameter, punctures larger than those of scutum. Metasomal terga as those of female. Structure. Malar space closed posteriorly. Pygidial plate with rounded apex. S8, Fig. 28.

Distribution. Argentina, provinces of Jujuy, Salta, Tucumán, Santiago del Estero, Catamarca, La Rioja, Córdoba, Santa Fe, Entre Ríos, Buenos Aires and Río Negro. Bolivia, department of Cochabamba.

Studied material. ARGENTINA. Jujuy: 3 F, 5 M, Ruta 9, S Monumento Trópico de Capricornio, $500 \mathrm{~m}$, 7-XII-1976, L. Stange (IFML); $1 \mathrm{~F}$, $1 \mathrm{M}$, Tilcara, $2400 \mathrm{~m}$, 25-I-1948, Monrós \& Willink (IFML); 1 M, Tilcara, II-1991, M. Fritz (MACN); 3 M, Tumbaya, 7-XII-1976, L. Stange (IFML). Salta: 1 F, Tacuil, 1-15-I-1969, A. Willink \& L. Stange (IFML); $1 \mathrm{~F}$, Tacuil, $2400 \mathrm{~m}$ (trampa Malaise), 16-31-I-1969, Willink, Terán \& Stange (IFML); 2 F, 4 M, Sumalao, 1-I-1990, XII-1990, I1992, M. Fritz (MACN); 3 F, 8 M, Rosario de Lerma, XII-1982, XII-1985, I-1986, XI-1992, M. Fritz (MACN); 1 M, Orán, Aguas Blancas, I-1950, E. O. Vollenweide (MLP); 1 F, Orán, Abra Grande, 4-15-XII-1967, R. Golbach (IFML); 1 M, Alemanía, 27-IV-1970, L. Stange \& C. Porter (IFML); 1 M, Chicoana, XII-1990, M. Fritz (MACN); 1 M, Coronel Moldes, XII-1990, M. Fritz (MACN). Tucumán: 1 F, Raco, 4-IV-1977, Erb \& Fidalgo (IFML); 2 M, Raco, 18-I-1973, L. Stange (IFML); $1 \mathrm{M}$, Tafí del Valle, III-1955, M. Manfrini (IFML); $3 \mathrm{M}$, Tucumán, Plaza Independencia, $430 \mathrm{~m}, 1-$ III-1969, W. Weyrauch (IFML); 1 M, ciudad Tucumán, 24-XI-1965, L. Stange (IFML); 1 M, Trancas, San Pedro de Colalao, 15-III-1949, Guanuco (IFML); 1 M, Trancas, I-1987, M. Fritz (MACN). Santiago del Estero: 1 F, Termas de Río Hondo, Dique Frontal, 20-V-1980, C. Porter (IFML). Catamarca: $1 \mathrm{~F}$, Los Nacimientos de Abajo (trampa Malaise), 1-15-I-1969, Willink, Terán \& Stange (IFML); 1 F, 1 M, El Rodeo, 1300 m, 28-I-1989, A. Willink (IFML); $1 \mathrm{M}$, Rodeo, 1500 m, 8-28-I-1959, R. Golbach (IFML); 2 M, El Rincón, 8-II-1968, A. \& E. Willink (IFML); 1 M, Pirquitas, 13-II-1958, R. Golbach (IFML). La Rioja: $1 \mathrm{M}$, San Francisco (MACN); $1 \mathrm{~F}$, Malanzán, I-1923, M.Gómez (MACN). Córdoba: 1 F, Villa Ciudad América, Dique Los Molinos, I- 


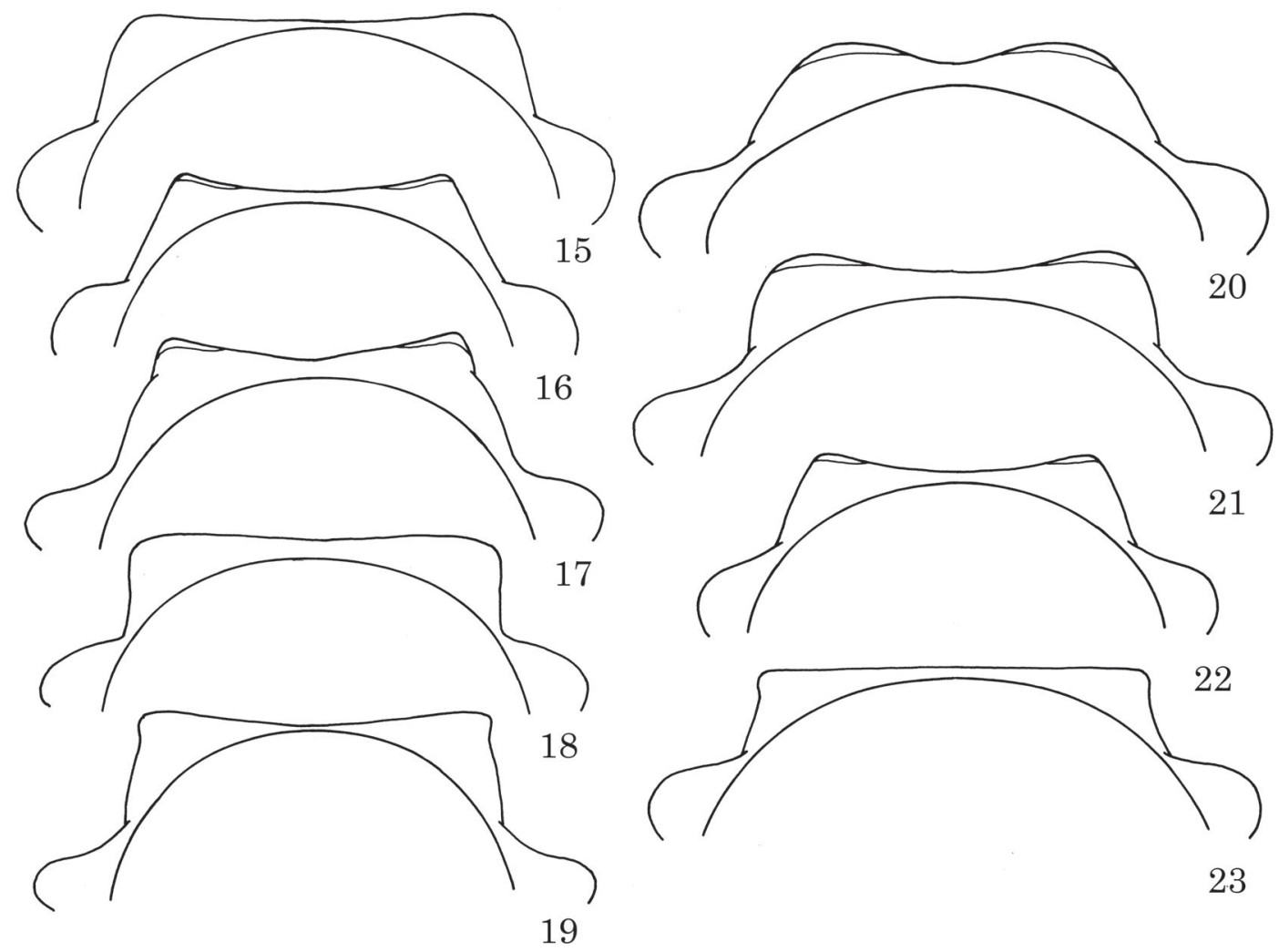

Figs. 15-23. Outline of the pronotal collar, pronotal lobes, and anterior margin of scutum in dorsal view. 15, bonaerensis; 16 costalis; 17, holmbergiana; 18, mesopotamica; 19, longula; 20, missionica; 21, turrigera; 22, chacoana; 23, pampicola.

1981, A. Willink (FIML); 1 M, Dique Los Molinos, II-1974, A. Willink (FIML); 2 F, 3 M, Bialet Massé, 11-I-3-II-1976, A. Willink (FIML); 1 F, 2 M, La Cruz, III-1970, A. Martínez (MACN); 1 M, Los Reartes, III-1974, A. Martínez (MACN); $1 \mathrm{M}$, Dpto. Calamuchita, El Sauce, XII-1938, M.J. Viana (MACN); 2M, Roca, $5 \mathrm{Km}$ N Realicó, 18XII-2006, Torretta, Cilla \& Montaldo (MACN). Santa Fe: 1 F, Rosario, 24-I-1922, Hubrich (ZSM); 1 M, Josefina, IV-1993, G. Williner (MACN). Entre Ríos: 2 F, Diamante, 4-IV-1918, A. Frers (MACN); 1 M, Paraná, April, Burmeister (MACN). Buenos Aires: 1 M, Pdo. Saavedra, Lag. Las Encadenadas, 28-II-2000, A. Roig A. (MACN). Río Negro: 1 M, Río Colorado, III-1958, A. Ogloblin (MLP). BOLIVIA. $1 \mathrm{~F}$, Cochabamba, 2000 m, 25-XI-1948, Zischkak (MLP).

\section{Nomada mesopotamica n. $s p$.}

(Figs. 3, 7, 18, 29)

The number of submarginal cells is variable in this species. Three of 19 studied specimens have two instead of three cells. In one specimen both wings have the vein $1^{\text {st }} \mathrm{r}$-m reduced to a short posterior stub, while in the other two specimens it is the second abscissa of vein Rs which is reduced, still recognizable by a short anterior stub. Thus, the two-celled condition has been reached by the loss of different veins in different specimens of this species. Variation in the number of submarginal cells has been noted by Michener (1954) for N. trapidoi Michener, the males of which have three submarginal cells, but the females only two. In this regard, Alexander (1994) mentioned N. trapidoi, and N. panamensis Michener as variable.

Diagnosis. This species, together with bonaerensis, is characterized by the simple hairs on the hypostomal area of the female. Males of bonaerensis also have simple hairs on the hypostomal area, but males of mesopotamica have branched hairs intermediate with the plumose hairs seen in other species. This species is also distinguished by the upper end of the metapleuron, which is tuberculate anteriorly and not transversely keeled as in the other Argen- 
tinean species, by the infuscate forewing with a clear preapical spot and yellowish pterostigma, and by the polished, evenly convex, sparsely punctate lower half of the face in both sexes.

Female holotype. Length: $8.2 \mathrm{~mm}$ (paratype, $8.2 \mathrm{~mm}$ ); length of forewing $6.8 \mathrm{~mm}$ (paratype, $6.7 \mathrm{~mm}$ ). Color. Black with following parts reddish: mandible, pronotal collar and pronotal lobe, posterior part of mesopleuron, scutum, scutellum, lower part of propodeum, and bases of T1T2. Scape, pedicel, flagellum, and legs beyond coxae yellowish brown. With yellow marks as follows: clypeus with triangular spot, supraclypeal area with irregular spot, paraocular area with broad band from lateral margin of clypeus to eye margin and then along eye margin reaching summit of eye, where it may be narrowly connected to band on upper half of posterior eye margin, pronotal collar with or without median mark, axilla with spot, T1-T2 with preapical bands expanded laterally, T4-T5 may bear preapical median streak. Sterna without maculation. Forewing infuscate, except hyaline spot at level of veins second $\mathrm{r}-\mathrm{m}$ and second $\mathrm{m}$-cu; hind wing infuscate, darker apically; veins dark brown; pterostigma yellowish, clothed with yellowish hairs, contrasting with dark hairs of remainder of wing. Sculpture. Clypeus shiny, with row of punctures close to apical margin, with median nearly impunctate area, and laterally with scattered small and moderate punctures irregularly distributed. Paraocular area with sparse punctures separated by $0.5-2.0$ puncture diameters. Supraclypeal area shiny, polished, with a few large punctures. Scutum polished, disc of scutum flat, with median longitudinal line and parapsidal lines distinct, but not set in furrows; punctures with diameter of 8-12 $\mu$, denser on margins of scutum, larger on anterior margin, where they are separated by $0.5-1.0$ puncture diameter; punctures progressively finer towards center of scutum, which is nearly impunctate. Scutellum with dorsal surface flat, with sparse punctures and weakly indicated median depression; posterior surface short, half as long as dorsal surface, rounded in profile. Mesopleuron densely punctured; punctures larger than those of scutum, separated by 0.3-0.5 puncture diameter. Metapostnotum roughened, with upper lateral angle microstriate. Base of T1 polished, with extremely fine, sparse punctures, contrasting with base of T2 with dense, small punctures; depressed apical band of T2 with sparse fine punctures bearing long hairs. Vestiture. Hairs on scutum 0.7-1.5 times MOD, on mesopleuron hairs with curved apices 1.3-2.8 times MOD; metasoma with long hairs on T3-

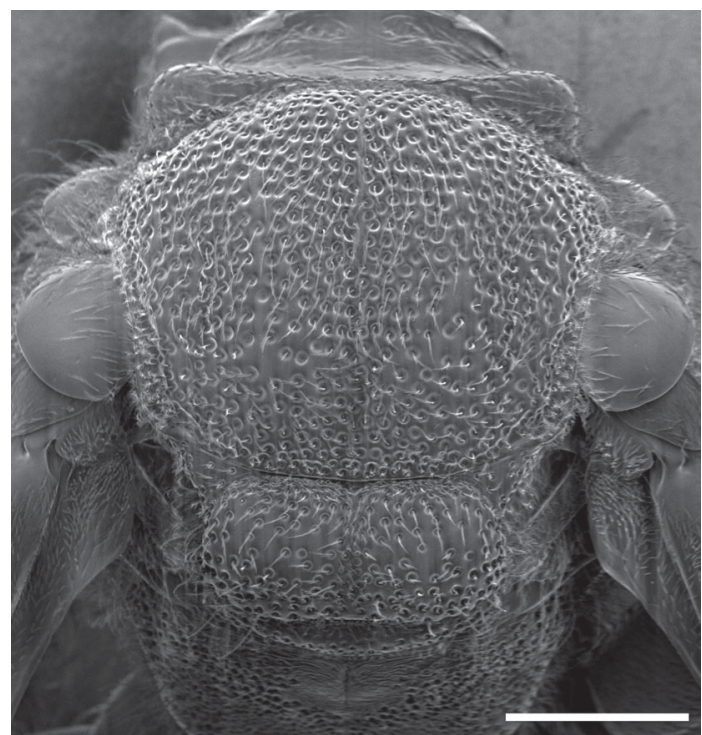

Fig. 24. Nomada bonaerensis, male, dorsal view of mesosoma. Scale line, $0.5 \mathrm{~mm}$.

T5, hairs at sides of T3-T4 1.5-2.3 times MOD. Hypostomal area with slender, simple hairs. Structure. Clypeus, supraclypeal area, and paraocular areas forming even, moderately convex surface; epistomal and subantenal sutures not set in furrows. Proportion POD:OOD, 1:1.55; IAD:AOD, 1:0.95. Antennal sockets above middle of face, proportion CA:AMO, 1.95:1. Scape 2.4 times as long as its apical width, compressed, with plical surface flattened, curved. Prontal collar in dorsal view with anterior margin slightly concave, weakly carinate; lateral angle rounded; collar wider than intertegular span (1:0.95). Dorsal surface of scutellum continuous with surface of scutum. Upper end of metapleuron without transverse keel. Supraspiracular ridge moderately developed above and behind propodeal spiracle. Forecoxa with tooth-like projection. Hind and mid tibiae on dorsal surface with coarse, dark spiniform setae arising from spicules. Apex of hind tibia with 5 large spiniform setae. Hind coxa expanded laterally, with dorsal outer margin narrowly rounded. Forewing usually with three submarginal cells, but in some specimens two, either by loss of $2^{\text {nd }}$ abscissa of Rs or of transverse $1^{\text {st }} \mathrm{r}$-m. Apex of marginal cell rounded.

Male. Length: 7.2-9.6 mm; length of forewing 6.0-7.8 mm. Color. Black, with reddish parts as in female, but yellow marks more extended as follows: basal half of mandible, base of labrum, entire malar area, most of clypeus except upper and lateral margins reddish to black, large spot 


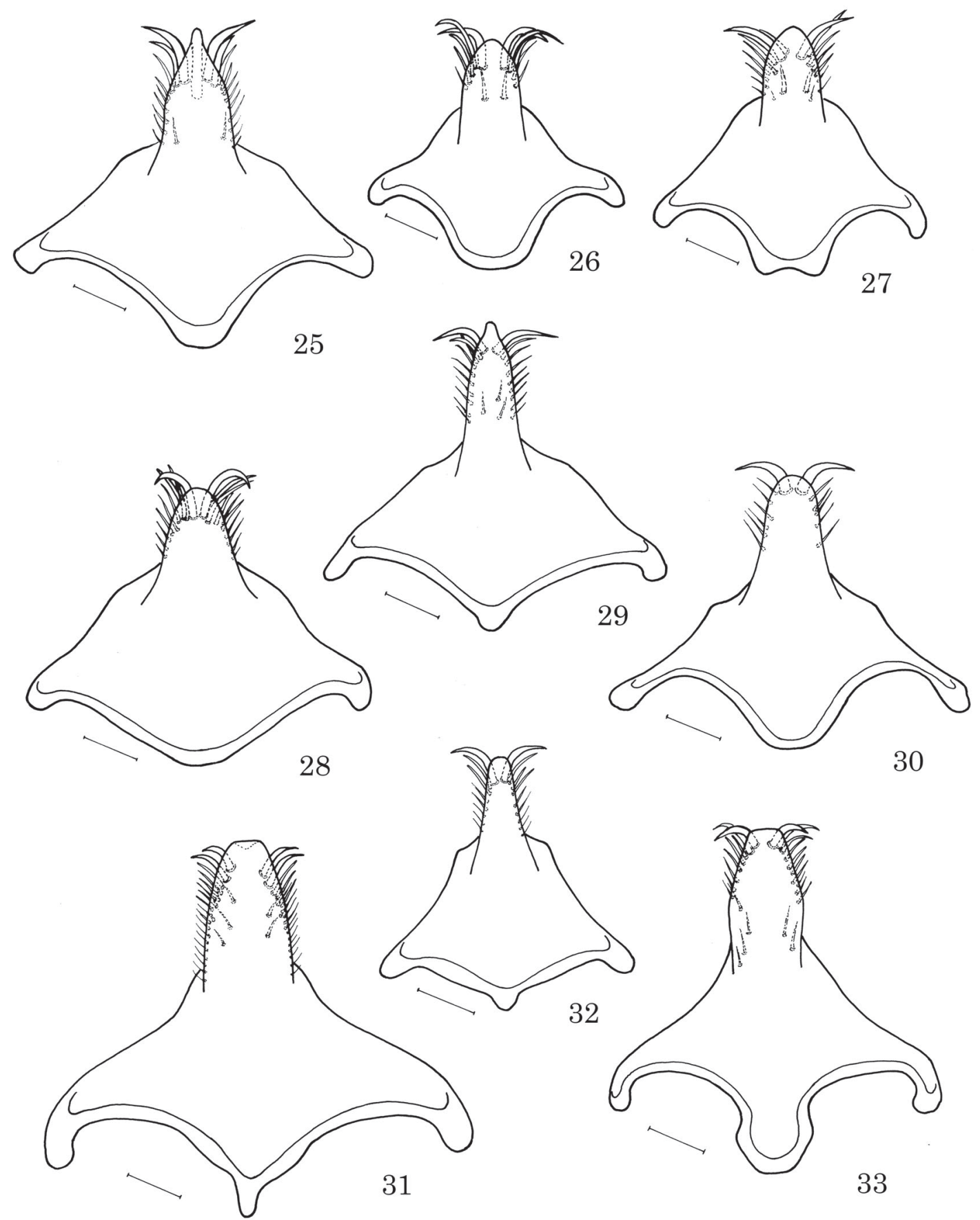

Figs. 25-33. Eighth metasomal sternum of male, ventral view. 25, pampicola; 26, holmbergiana; 27, costalis; 28, bonaerensis; 29, mesopotamica; 30, longula; 31, turrigera; 32, chacoana; 33, missionica.

on supraclypeal area, broad paraocular band, and complete band along posterior margin of eye; in some specimens malar space, clypeus, paraocular band and posterior orbital band forming uninterrupted yellow area. Yellow marks also present on middle of pronotal collar, axilla, preapical bands on T1-T2, and preapical streaks on T3-T5, which may be interrupted medially. In some specimens mesopleuron with median transverse reddish band, reddish spot anteriorly to hypoepimeral area, and reddish spot in front of mid coxae. Sculpture. Clypeus, supraclypeal area, meso- 
pleuron, metapostnotum and metasomal terga, as that of female. Paraocular area with punctures separated by 0.3-0.5 puncture diameter. Scutum with median longitudinal line and parapsidal lines distinct, but not set in furrows; punctures with diameter of 25-40 $\mu$, denser (separated by 0.3-1.0 puncture diameter) around margins of scutum and along median longitudinal line; between parapsidal and median longitudinal lines punctures sparser, separated by 0.5-3.0 puncture diameters. Scutellum with median longitudinal furrow stronger than that of female, giving bilobate appearance. Structure. Malar space narrowly open posteriorly, as long as 0.2 times basal width of mandible. Pygidial plate with rounded apex. S8, Fig. 29.

Etymology. The specific name refers to the geographical area where the species occurs.

Distribution. Argentina, provinces of Corrientes and Misiones. Paraguay, department of Caaguazú.

Material studied. ARGENTINA. Holotype female, Province of Corrientes, Ituzaingó, IX-1979, M. Fritz (MACN). Following paratypes: Corrientes: $1 \mathrm{~F}$, 16 M, Ituzaingó, IX-1979, M. Fritz (MACN, IFML). Misiones: 1 F, Bompland, 12-I-1911, P. Jörgensen (MLP). PARAGUAY. 1 M, Santa Rosa, X-1979, M. Fritz (MACN). Caaguazú: 1 M, Caaguazú, XII-1977, M. Fritz \& A. Martínez (MACN).

Nomada costalis Brèthes

(Figs. 4, 8, 16, 27, 34-35)

Nomada costalis Brèthes, 1909: 249 (Lectotype male, San Bernardino, Paraguay, K. Fiebrig, MACN, examined, present designation). Schrottky, 1913: 263. Alexander \& Schwarz, 1994: 241. Moure \& Melo, 2007: 595.

Hypochrotaenia (Hypochrotaenia) costalis: Snelling, 1986: 9.

Brèthes (1909) did not indicate the sex in the original description, nor the number of specimens that he examined. There is a single male specimen in the collection at MACN with the labels «10137» «San Bernardino / Paraguay» «Nomada costalis n sp» (this one in Brèthes' handwriting), and a printed red label «Holotypus.» The number 10137 corresponds to the following entry in the registry books: «Agosto 3, 09, 1 Nomada costalis Brèthes, San Bernardino, Paraguay, dádiva Sr. K. Fiebrig.» The specimen is in good condition and it is designated lectotype.

Diagnosis. This species can be recognized by the laterally expanded hind coxa with the dorsal outer margin keeled, forming an angle near the apex (Fig. 4). It resembles holmbergiana in color and structure, but can be readily differentiated by the lack of yellow markings on the sterna and the presence of three submarginal cells on the forewing.

Female. Length: 6.2-7.2 mm; length of forewing 6.3-6.5 mm. Color. Black, with following parts reddish: mandible, areas around yellow markings of head and thorax, spot on posterior part of mesopleuron below hypoepimeral area, four longitudinal stripes on scutum, tegula, lower part of propodeum, base of T1, and in some specimens base of T2. Scape, pedicel, and first flagellomere yellowish brown. Legs beyond coxae reddish brown. With yellow marks as follows: triangular spot on clypeus, small spot on supraclypeal area (reddish in some specimens), paraocular band surpassing level of antennal socket, small upper spot behind eye, upper margin of pronotal collar, spot on pronotal lobe, transverse band on scutellum, spot on axilla, band on metanotum, anterior spot on mesopleuron, posterior spot on mesopleuron in some specimens (usually reddish), external margin of mid and hind coxae, broad preapical bands on T1-T2 and T5, small lateral band on T3 (sometimes absent), and narrow preapical band on T4 (sometimes weak and medially interrupted). Sterna without yellow markings. Forewing infuscate, darker basally and along anterior margin; hind wing also infuscate; veins dark brown, pterostigma light brown. Sculpture. Clypeus, supraclypeal and paraocular areas with scattered, irregularly distributed punctures, 1-3 puncture diameters appart, leaving shiny interspaces between them. Punctures above level of antennal sockets strong, separated by less than half puncture diameter. Scutum polished, with median longitudinal line impressed, distinct but not in deep furrow. Disc of scutum between lateral margin and parapsidal furrow, and between latter and median longitudinal furrow, with nearly impunctate, polished, longitudinal bands; along furrows punctate; punctures with diameter of 10-15 $\mu$, denser on margins of scutum, on anterior margin separated by one half to one puncture diamenter. Scutellum with sparse punctation, similar to that of paraocular area; posterior surface rounded in profile, with stronger punctation and shallow longitudinal median depression. Mesopleuron with punctures larger than those of scutum, separated by 0.2 0.5 puncture diameters. Metapostnotum roughened, microstriate at sides. Base of T2 finely and densely punctate; preapical yellow band and apical band with finer, sparser punctures. Vestiture. 
Hairs on scutum 0.7-1.4 times MOD, on mesopleuron hairs with curved apices 1.8-2.8 times MOD; metasoma with long hairs on T3$\mathrm{T} 5$, hairs at sides of T3-T4 1.5-2.0 times MOD. Hypostomal area densely covered with short, plumose hairs. Structure. Clypeus and paraocular areas forming even, moderately convex surface; subantenal sutures slightly depressed. Proportion POD:OOD, 1:1.35; IAD:AOD, 1:0.8. Antennal sockets above middle of face, proportion CA:AMO, 1.75:1. Scape 2.4 times as long as its apical width, compressed, with plical surface flattened, curved. Labrum rectangular, 1.9 times as wide as long, with three preapical denticles, laterally carinate. Prontal collar in dorsal view with anterior margin concave; lateral angle angulose, dorsally carinate; collar narrower than intertegular span (1:1.23-1.25). Dorsal surface of scutellum separated from scutum by weak, transverse furrow. Upper end of metapleuron transversely keeled. Supraspiracular ridge moderately developed above propodeal spiracle. Forecoxa with tooth-like projection. Hind and mid tibiae on dorsal surface with coarse, dark spiniform setae arising from spicules. Apex of hind tibia with 3-4 large spiniform setae. Hind coxa expanded laterally, with dorsal outer margin keeled; in dorsal view angulose (Fig. 4). Forewing with three submarginal cells. Apex of marginal cell narrowly rounded.

Male. Length: 5.7-7.6 mm; length of forewing 5.0-6.2 mm. Color. Similar to that of female, but reddish areas of head and thorax reduced, and yellow markings on head more extended. Base of mandible and labrum yellow, clypeus largely yellow except upper and lateral margins, yellow malar area usually continuous with wider paraocular band. Scape with anterior yellow (sometimes reddish) longitudinal stripe. Posterior spot on mesopleuron usually yellow. Metasomal bands broad on T1-T2, narrow on other terga; on T1-T2 and on T6 complete, on $\mathrm{T} 3-\mathrm{T} 4$ reduced to lateral bands, and on T5 interrupted in middle. Sculpture. Clypeus at sides and along apical margin with punctures separated by 0.3-0.5 puncture diameter; medially with polished, impunctate area. Paraocular area also with punctures separated by 0.3-0.5 puncture diameter; punctures larger on supraclypeal area. Scutum anteriorly, posteriorly and along median longitudinal line with large, deep punctures with diameter of 40-60 $\mu$, separated by $0.2-0.5$ puncture diameter; disc of scutum with similar punctures irregularly distributed, leaving impunctate areas as large as 1-2 puncture diameters. Median longitudinal line set in furrow; parapsidal lines distinct, slightly depressed. Mesopleuron strongly punctured; punctures as large as those of scutum, separted by 0.1-0.3 puncture diameter. Metapostnotum and metasomal terga as those of female. Structure. Malar space closed posteriorly. Pygidial plate with rounded apex. S8, Fig. 27.

Distribution. Argentina, provinces of Salta, Misiones, and Corrientes. Paraguay, departments of Cordillera and Caaguazú.

Material studied. ARGENTINA. Salta: 2 M, Orán, Aguas Blancas, XII-1959 (MLP). Misiones: 2 M, Puerto Esperanza, X-1978, M. Fritz (MACN); 2 M, 7597 (MACN); 1 F, 1 M, Loreto, 12-IV-1948, A. Ogloblin (MLP). Corrientes: 3 F, Las Marías, ca. Virasoro, 10-15-XI-1969, VI-1971, C. Porter (IFML). BOLIVIA. 1 M, 11864, Provincia del Sara, J. Steinbach (MACN). PARAGUAY. Cordillera: $1 \mathrm{M}$, holotype, San Bernardino, K. Fiebrig (MACN). Caaguazú: 1 F, 5 M, Sommerfeld, este de Caa-Guazú, IV-1960, Andrae (IFML).

\section{N. holmbergiana $n . n$.} (Figs. 5, 9, 17, 26)

Hypochrotaenia parvula Holmberg, 1886: 273274 (Female, Formosa «Chaco», III-1885, type lost. Neotype female, Argentina, Province of Formosa, Formosa city, Laguna Oca, January 2009, G. Galvani, present designation, MACN) (preoccupied in Nomada by $N$. parvula Lucas, 1849). Dalla Torre, 1896: 335. Schrottky, 1903: 184. Schrottky, 1913: 263. Cockerell, 1916: 208. Sandhouse, 1943: 560. Snelling, 1986: 9. Alexander, 1994: 217. Michener, 2000: 624.

Nomada bicellularis: Ducke, 1912: 103 (partim). Alexander \& Schwarz, 1994: 241 (partim). Moure \& Melo, 2007: 595 (partim).

Based on Holmberg's (1886) detailed description it is possible to recognize this species with certainty, in spite of the loss of the type specimen. Nevertheless, with the purpose of fixing the meaning of the genus-level name Hypochrotaenia Holmberg, of which $H$. parvula is the type species, I here designate a neotype specimen from the same geographical area of the lost type.

Ducke (1912) considered Holmberg's Hypochrotaenia parvula and his Nomada bicellularis (Ducke, 1908) as color variants of the same species. The specimen that he described as bicellularis from the lower Amazon was darker than a single specimen that he examined from Paraguay, attributed to $H$. parvula, which had 
extended reddish coloration on the clypeus, scutum and scutellum. Since he considered Hypochrotaenia as a synonym of Nomada, and the name parvula was preoccupied in Nomada (see synonymy above), he applied the name $N$. bicellularis to the species, an action followed by subsequent authors. I have not seen types or specimens that I can attribute to $N$. bicellularis, but the color pattern that Ducke describes (1908) suggests that his species, although probably closely related, is different from Holmberg's $H$. parvula. The location of Ducke's types of $N$. bicellularis is unknown (Moure \& Melo, 2007).

In the South American species of Nomada that I have studied, the extent of red and black usually varies among specimens of the same species. This variation is particularly remarkable in $N$. pampicola, and to a lesser extent it is present in costalis and holmbergiana. On the contrary, the position and extent of the yellow markings is notably stable. It is the pattern of yellow markings that differs between Ducke's description of bicellularis and specimens of holmbergiana. The metasoma of bicelularis has yellow preapical bands on T1-T2, while in holmbergiana there are also yellow preapical bands on T3-T5, as well as sternal bands on S3-S4; these bands are conspicuous and could have not gone unnoticed to Ducke, who described the color pattern of bicellularis in detail. On the other hand, the pronotal collar, the pronotal lobes, and the lateral margins of the scutum are yellow in bicellularis, while in holmbergiana only the upper margin of the pronotal collar is yellow, and in dark specimens the scutum is laterally black, not marked with yellow. This differences in the pattern of maculation suggest two different species, and accordingly I here propose a new name for $H$. parvula.

Diagnosis. This species can be recognized, among those with laterally expanded hind coxa, by the pronotal collar with the sides converging anteriorly and the lateral angles with a distinct short carina. The median longitudinal and the parapsidal lines of the scutum are set in distinct furrows. Although the number of submarginal cells seems to be variable in some species, all specimens of holmbergiana that I have examined have two submarginal cells due to the loss of $1^{\text {st }}$ r-m.

Female. Length: 6.3-7.6 mm; length of forewing 5.4-6.5 mm. Color. Black, with following yellow marks: triangular spot on clypeus, small spot on supraclypeal area, basal spot on mandible, paraocular band nearly touching epistomal suture below and almost reaching top of eye above, short upper postorbital band, upper margin of pronotal collar, anterior and posterior spots on mesopleuron, lateral spot on scutellum, transverse band on metanotum, external margin of mid and hind coxae, entire preapical bands on T1-T2, wider laterally, preapical bands on T3-T4 usually interrupted medially, but in some specimens entire on $\mathrm{T} 4$, broad preapical band on $\mathrm{T} 5$, briefly interrupted medially, lateral preapical bands on S3-S4. Clypeal and supraclypeal spots sometimes reddish instead of yellow, and nearly disappearing in dark specimens. Paraocular and postorbital bands sometimes uniting on top of eye. Following parts reddish: labrum, underside of flagellum, pronotal lobe, tegula, legs beyond coxae, and narrow areas around yellow marks on head, pronotum and mesopleuron. Reddish areas on scutum variable, in light specimens scutum reddish with black restricted to anterior and posterior margins; in dark specimens scutum black on all margins and along median longitudinal line. Scape, pedicel, and first flagellomere yellowish brown. Forewing infuscate, darker basally and along anterior margin; hind wing also infuscate; veins and pterostigma brown. Sculpture. Clypeus close to apical margin with irregular row of large punctures, separated by $0.2-1.0$ puncture diameter; on center of clypeus punctures smaller, irregularly distributed, becoming very small close to epistomal suture. Paraocular and supraclypeal areas with punctures as large as those on center of clypeus, separated by 0.2 1.0 puncture diameter. Scutum polished, with median longitudinal line and parapsidal lines set in deep furrows. Punctures of scutum with diameter of 15-30 $\mu$; punctures denser on anterior third and on paramedian band coincident with parapsidal line, separated by $0.2-1.0$ puncture diameter; punctures between paramedian band and median longitudinal furrow smaller and sparser, leaving irregular impunctate interspaces. Mesopleuron with punctures larger than those of scutum, separated by 0.2-0.5 puncture diameter. Metapostnotum roughened, microstriate at sides. Base of T2 finely and densely punctate; preapical yellow band and apical band with finer, sparser punctures. Vestiture. Hairs on scutum 0.61.0 times MOD, on mesopleuron curved hairs 1.01.6 times MOD; metasoma with long hairs on T3$\mathrm{T} 5$, hairs at sides of T3-T4 0.6-1.0 times MOD. Hypostomal area densely covered with short, plumose hairs. Structure. Clypeus, supraclypeal area, and paraocular areas forming moderately convex surface; subantenal sutures and epistomal suture below tentorial pits slightly depressed. Proportion POD:OOD, 1:1.05; IAD:AOD, 1:0.9. Antennal sockets above middle of face, proportion 
CA:AMO, 1.5:1. Scape 2.5 times as long as its apical width, compressed, with plical surface flattened, curved. Labrum 1.5 times as wide as long, with three preapical denticles, laterally carinate. Prontal collar in dorsal view with anterior margin concave; lateral angle angulose, dorsally strongly carinate; collar narrower than intertegular span (1:1.20). Dorsal surface of scutellum separated from scutum by weak, transverse furrow. Upper end of metapleuron tuberculate, posteriorly keeled. Supraspiracular ridge moderately developed above propodeal spiracle. Forecoxa with long apical spine. Hind and mid tibiae on dorsal surface with coarse, dark spiniform setae arising from spicules. Apex of hind tibia with 4-5 large spiniform setae. Hind coxa expanded laterally, with dorsal outer margin narrowly rounded. Forewing with two submarginal cells, transverse $1^{\text {st }} \mathrm{r}-\mathrm{m}$ lost. Apex of marginal cell narrowly rounded.

Male. Length: 6.2-7.5 mm; length of forewing 5.1-6.0 mm. Color. Similar to that of female, but yellow marks more extended on head: paraocular band broader, continuous with yellow malar area; basal half of mandible, labrum and anterior surface of scape yellow. Scutum reddish with anterior and posterior margins black to entirely black. Metasomal preapical bands entire on T1-T2, interrupted in middle on T3-T6. Sculpture. Punctation of head similar to that of female, but punctures on supraclypeal area denser, separated by 0.2-0.5 puncture diameter. Scutum polished, with median longitudinal line and parapsidal lines set in deep furrows. Punctures on disc of scutum large, with diameter of 40-60 $\mu$, irregularly distributed, separated by $0.2-0.5$ puncture diameter and leaving some polished interspaces as large as 1.0-1.5 puncture diameters. Mesopleuron with dense punctures as large as those of scutum, separated by $0.2-0.5$ puncture diameter. Metapostnotum and metasomal terga as those of female. Structure. Malar space closed posteriorly. Pygidial plate with rounded apex. S8, Fig. 26.

Distribution. Argentina, provinces of Salta, Formosa, and Misiones. Paraguay, departments of Caaguazú, Cordillera, Paraguarí and Guayra. Brazil, state of Mato Grosso.

Material studied. ARGENTINA. Misiones: 1 F, Iguazú, XII-1991, A. Martínez (MACN). Formosa: 1 F, Formosa, Laguna Oca, January 2009, G. Galvani (Neotype, MACN). Salta: 1 M, Tablillas, II-1945, A. Marínez (MLP); 1 F, 1 M, Embarcación, XI-1989, A. Roig A. (MACN).
PARAGUAY. Caaguazú: 2 M, Sommerfeld, IV1960, Andrae (IFML). Cordillera: 1 F, San Bernardino, K. Fiebrig (MACN). Paraguarí: $1 \mathrm{M}$, Chaco, Cerro León, X-1979, M. Fritz (MACN). Guayra: 1 M, Colonia Independencia, 26-III-1951, Foerster (IFML). BRAZIL. Mato Grosso: 1 F, 50 km SE of Rondonópolis, 11-III-1980, R.B. Roberts (MACN).

Nomada longula $n . s p$.

(Figs. 11, 19, 30)

Diagnosis. This species belongs in a group characterized by an elongate body, yellowish wings, and forewing with two submarginal cells due to the loss of the second abscissa of the vein $\mathrm{Rs}$. Among them longula can be recognized by the shape of the pronotal collar, with the lateral angles nearly right-angular, not acute as in the other species, and by the expanded hind coxa keeled on the apical third only.

Male holotype. Length: $8.8 \mathrm{~mm}$; length of forewing $7.8 \mathrm{~mm}$. Color. Dark reddish brown with following parts yellow: mandible except apex, labrum, narrow anterior and posterior orbital bands (former reaching top of eye, latter interrupted on upper fifth), malar area, anterior fourth of hypostomal area, triangular spot on clypeus, small spot on supraclypeal area, small spot below median ocellus, spot on lateral angle of pronotal collar, pronotal lobe, small spot on posterior lateral angle of scutum, spot on axilla, lateral band on scutellum, interrupted transverse band on metanotum, anterior and posterior and large ventral spots on mesopleuron, metasternum, large lateral ovoid spot on propodeal declivity, external margin of mid and hind coxae, lateral and apical bands on T1 forming an Ushaped mark, entire preapical bands on T2-T3, lateral band on $\mathrm{T} 4$, central area on $\mathrm{S} 1$, and broad median bands on S2-S3. Legs yellowish brown beyond coxae, but tibiae and femora with yellowish anterior surfaces; tibial spurs and tarsi yellowish. Wings amber, with yellowish veins and pterostigma. Sculpture. Clypeus close to lateral margins with dense punctures, separated by 0.3 0.5 puncture diameter, punctures larger and sparser towards center of clypeus, which bears a nearly impunctate triangular area broadest on clypeal margin. Paraocular and supraclypeal areas with large, dense punctures separated by 0.2 0.5 puncture diameter. Scutum strongly punctured; punctures with a diameter of 40-60 $\mu$, nearly coalescent on anterior margin, on rest of scutum separated by 0.2-0.5 puncture diameter, except along stripe between median furrow and 
parapsidal furrow where punctures are irregular, with some interspaces as large as one puncture diameter. Median longitudinal line set in deep furrow; parapsidal lines also set in furrows. Scutellum with median longitudinal depression from anterior to posterior margin, giving bilobed appearance; rounded in profile. Metapostnotum roughened, with upper lateral angle microstriate. Mesopleuron with large, strong punctures, separated by $0.2-0.5$ puncture diameter. $\mathrm{T} 1$ finely punctured; base of T2 as well as depressed apical margin with fine punctures. Vestiture. Head and mesosoma with short hairs, those on scutum 0.5-0.8 times MOD, on mesopleuron curved hairs 0.1-1.0 times MOD; metasoma with longer hairs on T3-T6, hairs at sides of terga 0.6-1.0 times MOD. Hypostomal area densely covered with short, plumose hairs. Structure. Face rather flat, but supraclypeal and inferior paraocular areas distinctly swollen and epistomal and subantennal sutures set in furrows; upper paraocular areas also swollen and swollen area between antennal sockets nearly reaching middle ocellus. Malar space open posteriorly, as long as 0.3 times basal width of mandible. Proportion POD:OOD, 1:1.35; IAD:AOD, 1:0.9. Antennal sockets well above middle of face, proportion CA:AMO, 2.4:1. Scape 2.6 times as long as its apical width, compressed, with plical surface flattened, curved. Labrum rectangular, 2.2 times as wide as long, without preapical denticles, laterally carinate. Prontal collar in dorsal view with anterior margin weakly concave; lateral angle angulose, dorsally carinate; collar narrower than intertegular span (1:1.12). Dorsal surface of scutellum continuous with surface of scutum. Upper end of metapleuron transversely keeled. Propodeal supraspiracular ridge low, poorly developed. Forecoxa with short apical tooth. Hind and mid tibiae on dorsal surface with coarse, dark, sharply pointed spiniform setae arising from spicules. Apex of hind tibia with 4 large spiniform setae. Hind coxa expanded laterally, with dorsal outer margin keeled on apical third. Forewing with two submarginal cells, $2^{\text {nd }}$ abscissa of vein Rs lost. Apex of marginal cell narrowly rounded. Pygidial plate with rounded apex. S8, Fig. 30.

Etymology. The specific name refers to the elongate shape of the body of this bee.

Distribution. Argentina, province of Misiones.

Material studied. Holotype male, ARGENTINA, province of Misiones, Departamento Iguazú, A. Urugua-i, IX-1954, R.N. Orfila (MACN).
Nomada missionica $n$. $s p$.

(Figs. 1, 14, 20, 33)

Diagnosis. This species is related to infrequens and turrigera by the shape of the scutellum, which has the dorsal surface flat but strongly punctured, and a projecting posterior margin, crenulate due to the coalescent, coarse punctures. It is readily distinguished from these species by the bilobate shape of the pronotal collar in dorsal view, which lacks definite lateral angles. The lateral angles of the pronotal collar are acute, projecting, in infrequens, and rounded in turrigera.

Female holotype. Length: $8.0 \mathrm{~mm}$ (paratypes 8.0-8.7 mm); length of forewing $6.6 \mathrm{~mm}$ (paratypes 6.3-6.8 mm). Color. Black with yellow and red marks. Following parts yellow: basal half of mandible, labrum, clypeus except black spot around tentorial pit, small supraclypeal spot, anterior and posterior orbital bands connected through malar area, but interrupted on top of eye, band on pronotal collar between lateral angles, spot on pronotal lobe, lateral margin of scutum, transverse band on scutellum briefly interrupted medially, large anterior and posterior spots and small ventral spot on mesopleuron, band along posterolateral margin of propodeum, lateral spot on mid coxa, lateral and ventral spots on hind coxa, anterior stripe on foretibia, apical spots on mid and hind tibiae, entire preapical bands on T1-T4, lateral band on T5, and preapical bands on S1-S5, that of S1 restricted to center and that on S5 interrupted in middle. Following parts reddish: scape, pedicel, base of first flagellomere, tegula, metapostnotum laterally, posterior and lateral surfaces of propodeum, base of $\mathrm{T} 1$, and narrow areas around yellow marks on top of eye, on pronotum and on mesopleuron. Foreleg reddish beyond coxa; mid leg reddish beyond coxa, but tarsus darkened; hind leg reddish, except dark posterior surface of femur and tibia, dark preapical area on anterior surface of tibia, and dark tarsus; tibial spurs reddish. Wings infuscate; forewing darker on marginal cell and on apex beyond closed cells; hind wing darker on apical third; veins and pterostigma dark brown. Sculpture. Clypeus, supraclypeal and paraocular areas similarly punctate, with strong punctures separated by $0.2-0.5$ puncture diameter; punctures above level of antennal socket similar to those of paraocular area. Integument of head and thorax between punctures polished, shiny. Punctures of scutum large, with diameter of 60-95 $\mu$, coalescent on most part, but between parapsidal line and lateral margin of scutum sparser, separated 

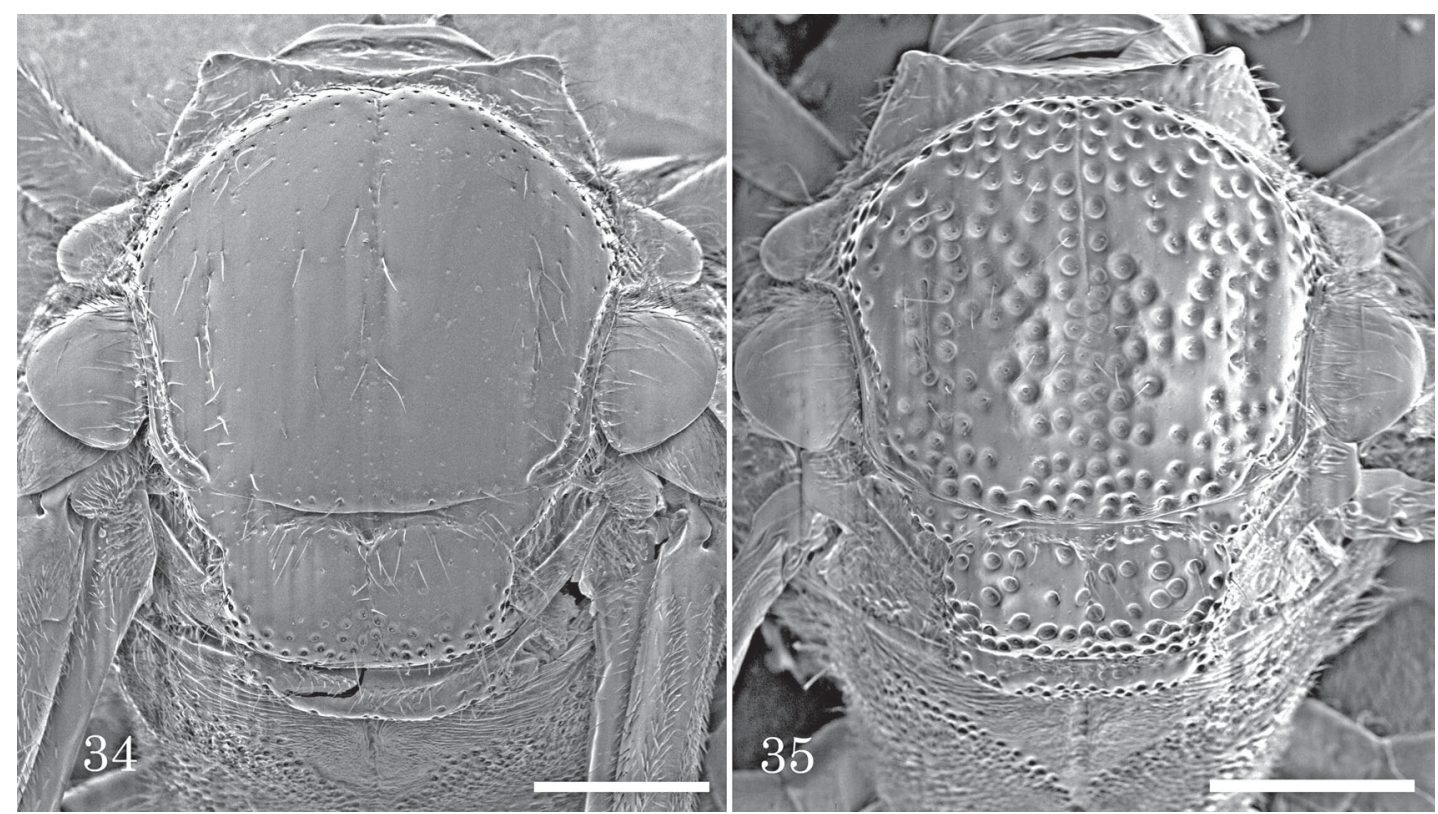

Figs. 34-35. Nomada costalis, dorsal view of mesosoma. 34, female; 35, male. Scale lines, $0.5 \mathrm{~mm}$.

by $0.2-0.4$ puncture diameter. Median longitudinal line and parapsidal lines at level of dorsal surface of scutum, not depressed. Scutellum with distinct dorsal horizontal and posterior vertical surfaces; dorsal surface bilobed posteriorly, with large, close punctures coalescent posteriorly forming crenulate margin; posterior surface with moderate punctures separated by $0.2-0.5$ puncture diameter. Mesopleuron with punctures as large as those of scutum, separated by $0.2-1.0$ puncture diameter. Metapostnotum microstriate. Base of T1 shiny, finely microsculptured, yellow band medially and apical band with sparse fine punctures; base of T2 densely, finely punctured, but apical band nearly impunctate. Vestiture. Short on most of body, hairs on scutum 0.7-0.8 times MOD, on mesopleuron hairs 0.7-1.2 times MOD; metasoma at sides with few erect hairs 0.7 times MOD. Hypostomal area densely covered with short, plumose hairs. Structure. Face convex, with supraclypeal area swollen, tuberculiform between antennal sockets; epistomal and subantennal sutures not depressed. Clypeus with apico-lateral concave triangular sector set off by carina from rest of clypeus. Proportion POD:OOD, 1:1.3; IAD:AOD, 1:0.75. Antennal sockets near middle of face, proportion CA:AMO, 1.3:1. Scape 2.0 times as long as its apical width. Labrum ovoid, 1.7 times as wide as long, with several irregular apical denticles, laterally carinate, medially with longitudinal impunctate stripe.
Prontal collar in dorsal view with anterior margin medially concave; anterior margin carinate on lateral third, lateral angle attenuate, not well defined; collar narrower than intertegular span (1:1.52). Dorsal surface of scutellum separated from scutum by deep, transverse furrow. Upper end of metapleuron transversely keeled. Supraspiracular ridge well developed above and behind propodeal spiracle. Forecoxa without apical spine or tooth. Hind and mid tibiae on dorsal surface with slender, whitish setae arising from spicules. Apex of hind tibia with minute spiniform setae (Fig. 1). Hind coxa not expanded laterally, dorsal outer margin broadly rounded. Forewing with three submarginal cells. Apex of marginal cell pointed on wing margin; marginal cell narrowed apical to $2^{\text {nd }}$ transverse r-m.

Male. Length: $7.0 \mathrm{~mm}$; length of forewing 6.1 $\mathrm{mm}$. Color. Black, with yellow marks similar to those of female in extent and position, except yellow on propodeum reduced to small spot, ventral spot on hind coxa absent, yellow marks on legs reduced, preapical bands present on T1-T6 and on S2-S5. Red areas nearly absent on head, and much reduced on thorax; propodeum red except small yellow spot on postero-lateral angle; other red areas as in female. Sculpture. Similar to that of female. Structure. Malar space narrowly open posteriorly, as long as 0.2 times basal width of mandible. Pygidial plate with notched apex. S8, Fig. 33. 
Etymology. The specific name refers to the geographical area where the species occurs.

Distribution. Argentina, provinces of Corrientes and Misiones.

Material studied. ARGENTINA. Holotype female, Province of Misiones, Apóstoles, San José, 19-XI-1980, Willink, Fidalgo, Claps \& Domínguez (IFML). Following paratypes: Misiones: $1 \mathrm{~F}$, Parque Nacional Iguazú, 10-XI-1973, Willink \& Tomsic (IFML); 2 F, Parque Nacional Iguazú, 24XI-1980, Willink, Fidalgo, Claps \& Domínguez (IFML, MACN). Corrientes: $1 \mathrm{M}$, ca. Corrientes, 8-20-XI-1969, trampa Malaise, C. Porter (IFML).

\section{Nomada turrigera n. $s p$.}

(Figs. 13, 21, 31, 36)

Diagnosis. This species is the largest Nomada in Argentina. The shape of the scutellum relates it to missionica and infrequens. It is known from the male only. It is distinguished by the outstandingly developed propodeal supraspiracular ridge, and the pedicel nearly hidden within the apex of the scape. This last feature is not present in any other Argentinean species.

Male holotype. Length: $10.6 \mathrm{~mm}$ (paratypes 9.2-9.7 $\mathrm{mm}$ ); length of forewing $7.9 \mathrm{~mm}$ (paratypes 6.8-7.2). Color. Black and red with following parts yellow: mandible except apex, labrum, clypeus, supraclypeal area, broad paraocular band extending from margin of clypeus and supraclypeal area to antennal socket, and then narrowing to upper fifth of eye, malar area, anterior fourth of hypostomal area, complete posterior orbital band, band on pronotal collar, upper spot on pronotal lobe, most of tegula, lateral margin of scutum, transverse band on scutellum, anterior vertical band and posterior and ventral spots on mesopleuron, ventral spot on hind coxa, preapical bands on T1-T6 and on S1-S5. Scape, pedicel and base of first flagellomere yellowish brown. Following parts red: legs and tibial spurs, upper spot on eye margin, paramedian longitudinal band on scutum, narrow areas around yellow marks of pronotum, mesopleuron, and scutellum, posterior surface and postero-lateral angle of propodeum, and base of T1. Wings moderately infuscate; forewing darker on marginal cell and on apex beyond closed cells; hind wing darker on apical third; veins and pterostigma dark brown. Sculpture. Clypeus, supraclypeal and paraocular areas with strong punctures separated by 0.3-0.8 puncture diameter. Punctures of scutum strong, dense,

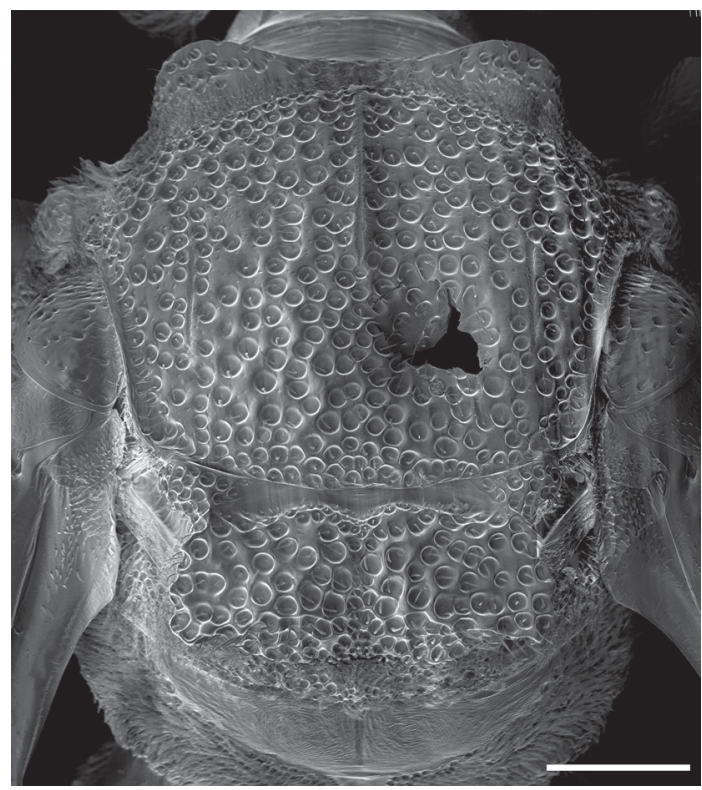

Fig. 36. Nomada turrigera, male, dorsal view of mesosoma. Scale line, $0.5 \mathrm{~mm}$.

with diameter of 50-70 $\mu$; most punctures separated by 0.1-0.3 puncture diameter, but sparser between parapsidal line and lateral margin of scutum. Median longitudinal line slightly elevated over surface of scutum; parapsidal line distinct, at level of dorsal surface. Scutellum with distinct dorsal horizontal and posterior vertical surfaces; dorsal surface with large, close punctures coalescent posteriorly forming crenulate margin. Mesopleuron with punctures as large as those of scutum, separated by $0.2-0.8$ puncture diameter. Metapostnotum microstriate. Base of T1 shiny, finely microsculptured, apical band with small punctures; base of T2 densely, finely punctured, apical band with small, sparse punctures. Vestiture. Short, hairs on scutum 0.5 times MOD, on mesopleuron hairs 0.5 times MOD; metasoma without erect hairs. Hypostomal area with plumose hairs, but not forming dense mat as in other species. Structure. Face convex, with supraclypeal area swollen, tuberculiform between antennal sockets; epistomal suture slightly depressed at level of tentorial pit. Malar space narrowly open posteriorly, as long as 0.2 times basal width of mandible. Proportion POD:OOD, 1:1.2; IAD:AOD, 1:0.9. Antennal sockets near middle of face, proportion CA:AMO, 1.34:1. Scape 2.0 times as long as its apical width, obconical, scarcely compressed; pedicel nearly completely hidden within apex of scape. Labrum ovoid, 1.8 times as wide as long, with three preapical denticles, laterally weakly carinate. Prontal collar 

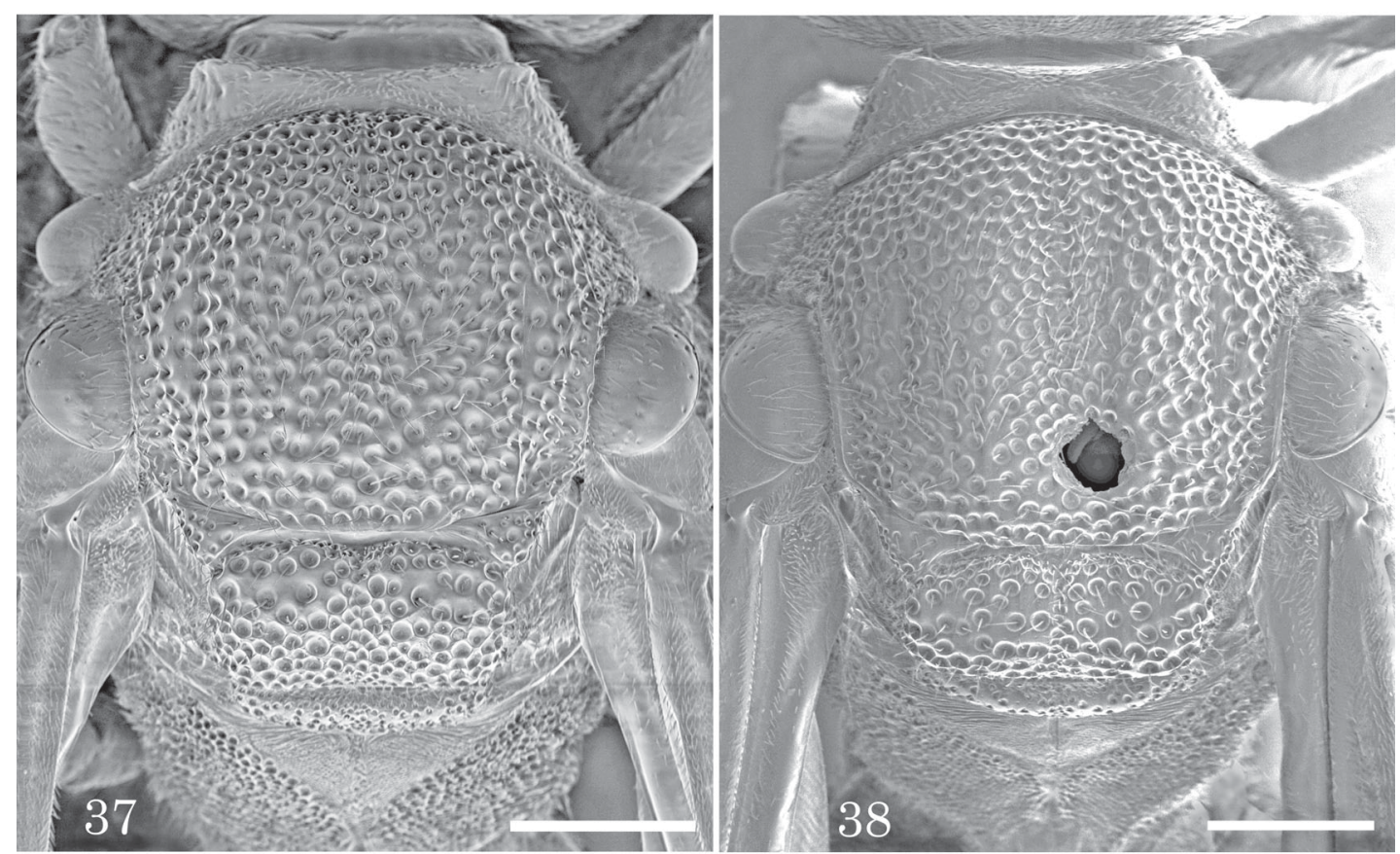

Figs. 37-38. Nomada chacoana, dorsal view of mesosoma. 37, male; 38, female. Scale lines, $0.5 \mathrm{~mm}$.

in dorsal view with anterior margin weakly concave; anterior margin carinate on lateral third, lateral angle angulose; collar narrower than intertegular span (1:1.20). Dorsal surface of scutellum separated from scutum by deep, transverse furrow. Upper end of metapleuron transversely keeled. Propodeal supraspiracular ridge outstandingly developed, projecting laterally, forming concavity above and behind spiracle. Forecoxa without apical spine or tooth. Hind and mid tibiae on dorsal surface with short, whitish setae arising from spicules. Apex of hind tibia without spiniform setae. Hind coxa not expanded laterally, dorsal outer margin broadly rounded. Forewing with three submarginal cells. Apex of marginal cell pointed on wing margin; marginal cell narrowed apical to $2^{\text {nd }}$ transverse $r-m$. Pygidial plate with notched apex. S8, Fig. 31.

Etymology. The specific name refers to the turret-like shape of the scutellum of this species. Dires.

Material studied. ARGENTINA. Holotype male, Province of Buenos Aires, $20 \mathrm{~km} \mathrm{SE}$ Magdalena, Estancia El Destino, 2-5-II-2000, A. Roig A. (MACN). Following paratypes: Buenos Aires: $3 \mathrm{M}, 20 \mathrm{~km}$ SE Magdalena, Estancia El Destino, 2-5-II-2000, A. Roig A. (MACN); 1 M,
Magdalena, XI-1998, sobre Scutia, A. Basilio (MACN).

Nomada chacoana $n . s p$.

(Figs. 2, 12, 22, 32, 37-38)

Diagnosis. This species resembles costalis and holmbergiana in coloration, size, and shape of the pronotal collar, but it is easily recognized by the rounded hind coxa, not expanded laterally, by the hind tibia with whitish setae arising form the spicules, and by the well-developed propodeal supraspiracular ridge. It shares with missionica and turrigera an elevated scutellum, separated from the scutum by a deep transverse furrow; it is distinguished from these species by the finer punctation, and by the forewing infuscate along the costal margin, not apically.

Female holotype. Length: $6.6 \mathrm{~mm}$ (paratypes 7.5-7.6 $\mathrm{mm}$; length of forewing $6.3 \mathrm{~mm}$ (paratypes 6.2-6.5 mm). Color. Black and red with following parts yellow: small spot on base of mandible, triangular spot on clypeus, small supraclypeal spot, paraocular band from margin of clypeus to almost reaching top of eye above, posterior orbital spot on upper fifth of eye, anterior margin of pronotal collar, transverse band on scutellum and metanotum (spot on axilla in one paratype), anterior and posterior spots on mesopleuron, spot on postero-lateral angle of propodeum hidden by 
dense whitish pubescence, lateral margin of mid and hind coxae, lateral and preapical bands on $\mathrm{T} 1$ forming U-shaped mark, broad preapical band on $\mathrm{T} 2$, narrow lateral bands on T3-T4, entire band on T5, broad median bands on S2-S3, lateral band on S4, and lateral spot on S5. Following parts red: most of mandible, labrum basally (dark apically), scutum except anterior and posterior black margins, and reddish areas around yellow marks on head, thorax and propodeum. Mesopleuron with weakly defined reddish spot in front of mid coxa. Scape, pedicel, and first flagellomere yellowish brown; pronotal lobe and tegula reddish brown. Legs reddish brown, with dark coxae, trochanters, under and posterior surfaces of mid and hind tibiae and femora, and mid and hind tarsi; tibial spurs yellowish. T1 and S1 dark reddish brown. Forewing with strongly infuscate band along anterior margin, occupying radial, first median, first submarginal, second submarginal, and marginal cells to wing apex; hind wing evenly moderately infuscate; veins and pterostigma dark brown. Sculpture. Clypeus with interspersed moderate and small punctures, larger punctures separated by 0.5-1.0 puncture diameter; punctures smaller close to epistomal suture. Supraclypeal and paraocular areas with punctures separated by 0.2-0.4 puncture diameter. Punctures above antennal sockets larger than those of lower paraocular area. Punctures of scutum with diameter of 45-60 $\mu$, coalescent on antero-lateral angle, on remainder of scutum separated by 0.1-0.3 puncture diameter. Median longitudinal line set in weak furrow; parapsidal lines not set in furrows. Scutellum with distinct dorsal horizontal and posterior vertical surfaces; dorsal surface with punctures similar to those of disc of scutum, posterior margin weakly bilobed. Mesopleuron with punctures larger than those of scutum, separated by 0.1-0.3 puncture diameter. Metapostnotum dull, microsculptured. Apical band of T1 finely and densely punctate; T2 with fine, dense punctures on entire surface. Vestiture. Hairs on scutum 0.5-0.8 times MOD, on mesopleuron curved hairs 0.5-1.0 times MOD; metasoma with hairs at sides of T3-T4 0.5-0.8 times MOD. Hypostomal area densely covered with short, plumose hairs. Structure. Face convex, swollen between antennal sockets; epistomal and subantenal sutures slightly depressed. Proportion POD:OOD, 1:0.95; IAD:AOD, 1:0.85. Antennal sockets above middle of face, proportion CA:AMO, 1.4:1. Scape 2.5 times as long as its apical width, compressed, with plical surface flattened, curved. Labrum 1.5 times as wide as long, with three preapical denticles, laterally cari- nate. Prontal collar in dorsal view with anterior margin concave; lateral angle angulose, dorsally carinate; collar narrower than intertegular span (1:1.20). Dorsal surface of scutellum separated medially from scutum by deep, transverse furrow. Upper end of metapleuron transversely keeled. Supraspiracular ridge well developed above and behind propodeal spiracle. Forecoxa with apical spine. Hind and mid tibiae on dorsal surface with slender, whitish setae arising from spicules. Apex of hind tibia with minute spiniform setae (Fig. 2). Hind coxa not expanded laterally, dorsal outer margin broadly rounded. Forewing with three submarginal cells. Apex of marginal cell narrowly rounded.

Male. Length: $6.5-8.0 \mathrm{~mm}$; length of forewing 5.4-6.7 mm. Color. Similar to that of female, but yellow marks more extended on head: mandible except apex, malar area, postorbital band occupying upper third of eye; triangular spot on clypeus and supraclypeal spot larger, without surrounding reddish areas. Ventral spot on mesopleuron usually yellow. Bands on T1-T6 and on S2-S4 usually not interrupted. S1 with or without central yellow spot. In some specimens anterior black margin of scutum extending posteriorly as two paramedian lines, and posterior black margin extending anteriorly as median longitudinal black line. Sculpture. Similar to that of female. Structure. Malar space narrowly open posteriorly, as long as 0.1 times basal width of mandible. Pygidial plate with notched apex. S8, Fig. 32 .

Etymology. The specific name refers to the geographical area where the species occurs.

Distribution. Argentina, provinces of Misiones, Tucumán, Santiago del Estero, and Formosa. Bolivia.

Material studied. ARGENTINA. Holotype female, Province of Santiago del Estero, Termas de Río Hondo, Dique Frontal, 20-V-1980, C. Porter (IFML). Following paratypes: Misiones: $1 \mathrm{M}$, Dos de Mayo, 10-XII-1965, A. Ogloblin (MLP). Formosa: 1 F, 2 M, I-1947, A. Reales (IFML). Santiago del Estero: 1 M, I-1943, Briones (IFML);; 1 F, 4 M, Las Termas, 21-V-1980, M. del V. Ajmat de Toledo (IFML, MACN). Tucumán: 1 M, Depto. Río Chico, Monte Bello, 14-III-1947, Willink \& Golbach (IFML); 1 M, 60 km NE S. M. Tucumán, abril (MACN). BOLIVIA. $1 \mathrm{M}$, Omboruzu (not located), 2200 m, 23-II-1960, R. Golbach (IFML). 
Nomada pampicola Holmberg

(Figs. 10, 23, 25)

Nomada pampicola Holmberg, 1886: 236-238 (Lectotype female, by present designation, «Nomada pampicola H. a.» MACN). Dalla Torre, 1896: 360. Schrottky, 1903: 184. Friese, 1908: 75. Jörgensen, 1909: 218. Cockerell, 1911: 651. Jörgensen, 1912a: 138; 1912b: 314. Schrottky, 1913: 263. Friese, 1916: 339. Cockerell, 1917: 237. Rodeck (in Cockerell, 1949): 457. Roig Alsina, 1991: 28, figure 4. Alexander \& Schwarz, 1994: 242. Silveira et al., 2002: 145. Moure \& Melo, 2007: 597.

Nomada carcaranensis Cockerell, 1917: 236-237 (Holotype male, Carcarañá, Argentina, L. Bruner. USNM, examined). Alexander \& Schwarz, 1994: 241. Synonymized by Moure \& Melo, 2007: 597.

Hypochrotaenia (Micronomada) pampicola: Snelling, 1986: 9.

Hypochrotaenia carcarensis (sic): Snelling, 1986, 13.

Holmberg (1886) described in detail a variety «a» from Baradero (Province of Buenos Aires, leg. F. Lynch Arribálzaga, 1878), and subsequently mentioned color differences of a variety «b» from Arrecifes (Province of Buenos Aires, leg. M. Oliveira César). The specimen from the Holmberg collection designated lectotype closely agrees with the description of the variety «a.» It bears three labels: one small red square, a white label with the female simbol marked with an upper and a lower red line, and another label in Holmberg's handwriting «Nomada pampicola H. a.» The specimen is in poor condition, lacking the antennae beyond the scapes, the right eye, most of the legs and the metasoma beyond the first segment; I have added a lectotype label.

Diagnosis. This species is readily recognized by its flat clypeus and supraclypeal area, and the straight anterior margin of the pronotal collar in dorsal view, with narrowly rounded lateral angles. The forewing is extensively infuscate with a clear preapical spot, the hind coxa is laterally rounded, not expanded, and the hind tibia bears on the dorsal surface whitish setae arising from the spicules.

Female. Length: 6.7-9.8 mm; length of forewing 5.8-7.5 mm. Color. Black and red with following marks yellow: paraocular band from epistomal suture to level of antennal socket, upper band on pronotal collar, spot on pronotal lobe, transverse band on metanotum, anterior and posterior spots on mesopleuron, lateral spots on mid and hind coxae, preapical bands on T1-T2 (broader laterally) and on T4-T5, and lateral spot on T3. The extent of black and red varies considerably in this species; regardless of this variation, yellow markings fairly constant. Darkest specimens with black labrum, and black longitudinal mark on middle of face which occupies entire clypeus and broadens above tentorial pits enclosing antennal sockets, ocelli and vertex; most of occipital region and hypostomal areas black. At other extreme of variation, light specimens extesively red with black markings restricted to upper margin of clypeus, small interalveolar spot, small spot between ocelli, and reduced area on occiput and hypostomal area; in these specimens yellow paraocular bands broader. Pronotum entirely black to entirely red. Scutum red with black anterior and posterior margins, and black median longitudinal stripe, width of which varies from 1-2 times MOD. Scutellum patterned with black to entirely red. Metanotum, metapostnotum, meso and metapleuron, and propodeum, entirely black to entirely red. Scape, pedicel, first flagellomere, and tegula yellowish brown. Legs red, but in some specimens coxae, hind trochanter, femur and tibia, patterned with black. Metasoma with reddish brown terga and blackish sterna. Wings infuscate; forewing with clear spot at level of second r-m and second m-cu; veins dark brown, pterostigma yellowish brown. Sculpture. Clypeus shiny, laterally and close to apical margin with moderate punctures separated by 0.5-1 puncture diameter, leaving median longitudinal impunctate stripe. Paraocular and supraclypeal areas with punctures similar to those of clypeus, denser close to antennal sockets. Scutum polished, with median longitudinal line slightly depressed and parapsidal lines distinct, but not set in furrows; punctures larger than those of clypeus, with diameter of $15-30 \mu$, separated by $0.3-2.0$ puncture diameter, irregularly distributed. Scutellum with dorsal surface flat, with irregular punctures separated by $0.2-1.5$ puncture diameter; posteriorly bilobate, with median longitudinal depression; posterior surface one third as long as dorsal surface. Mesopleuron densely punctured; punctures as large as those of scutum, separated by $0.2-0.5$ puncture diameter. Metapostnotum roughened, with upper lateral angle striate. T1 and T2 densely, finely punctate throughout. Vestiture. Hairs on scutum 0.5-0.7 times MOD, on mesopleuron curved hairs 1.0-1.5 times MOD; metasoma with hairs at sides of T3-T4 0.8-1.0 times MOD. Hypostomal area densely covered with short, plumose hairs. Structure. Face flat, with upper part of clypeus and supraclypeal area depressed; epistomal and subantenal sutures not set in furrows. Proportion POD:OOD, 1:1.25; IAD:AOD, 1:1.2. Antennal sockets above middle of face, proportion CA:AMO, 1.55:1. Scape 2.6 times as long as its apical width, compressed, with plical surface flattened, curved. Labrum rectangular, 1.9 times as wide as long, with three preapical denticles, 
laterally carinate. Prontal collar in dorsal view with anterior margin straight; lateral angle narrowly rounded; collar subequal to intertegular span (1:1.05). Dorsal surface of scutellum separated from scutum by weak, transverse furrow. Upper end of metapleuron tuberculate, posteriorly keeled. Supraspiracular ridge well developed above propodeal spiracle. Forecoxa with long apical spine. Hind and mid tibiae on dorsal surface with slender, whitish setae arising from spicules. Apex of hind tibia with 5-7 spiniform setae. Hind coxa not expanded laterally, dorsal outer margin broadly rounded. Forewing with three submarginal cells. Apex of marginal cell rounded.

Male. Length: 6.6-8.5 mm; length of forewing 6.0-7.8 mm. Color. Variation of black and red areas similar to that of female. Following parts yellow: basal half of mandible, triangular spot on clypeus, malar area, paraocular band as in female, upper band on pronotal collar, small spot on pronotal lobe, band on metanotum, anterior, posterior and ventral spots on mesopleuron, lateral spots on mid and hind coxae, preapical bands on T1-T2 and T4-T6 (sometimes interrupted on T4 and on T6; T3 without yellow marks), in some specimens narrow lateral band on S4. Sculpture. Punctation on head and thorax denser and stronger than that of female. Lower paraocular area with punctures separated by 0.1-0.5 puncture diameter. Punctures of scutum with diameter of 25-40 $\mu$, separated by $0.2-1.0$ puncture diameter; mesopleuron with punctures separated by 0.1-0.5 puncture diameter. Punctation on metasomal terga as that of female. Structure. Malar space closed posteriorly. Pygidial plate with notched apex. S8 with apical median longitudinal thickening, Fig. 25.

Distribution. Argentina, provinces of Jujuy, Salta, Tucumán, La Rioja, Córdoba, San Luis, San Juan, Mendoza, Santa Fe, Entre Ríos, Buenos Aires, La Pampa and Río Negro. Brazil, state of Rio Grande do Sul (Silveira et al., 2002).

Material studied. ARGENTINA. Jujuy: $1 \mathrm{~F}$, 7270 (MACN). Salta: 2 F, 1 M, Chicoana, XII-1990, I-1991, M. Fritz (MACN); 8 F, 12 M, Sumalao, 1-I1990, XII-1990, I-1992, XII-1995 M. Fritz (MACN); 2 F, 3 M, Rosario de Lerma, I-1985, XII-1985, XII1986, I-1990, M. Fritz (MACN); 1 F, 3 M, Coronel Moldes, 28-XII-1992, A. Roig Alsina \& L. Horovitz (MACN); 1 M, Cnel. Moldes, 2-II-1960, Ajmat (IFML); 3 F, Cnel. Moldes, II-1989, M. Fritz (MACN); 2 M, La Viña, II-1990, III-1992, M. Fritz (MACN); 2 M, Cobos, II-1991, M. Fritz (MACN); 1 M, Urundel, 20-21-IV-1949, Kormilev (IFML). Tucumán: 1 F, 2 M, Los Puestos, Dto. Leales, 11-
IV-1967, A. Willink (IFML). Córdoba: 1 F, Freyre, IV-1992, Williner (MACN). La Rioja: 2 F, Iliar (MACN); 2 F, Villa Unión, 12-XII-1971, Porter \& Stange (IFML). San Luis: San Francisco, 6-II-1958, Willink \& Tomsic (IFML). San Juan: 1 M, Pocitos, Rinconada, 26-I-1937 (MLP); 1 H, Desamparados, 27-XII-1922, M. Gómez (MACN). Mendoza: 1 F, 2 M, Mendoza, C. S. Reed (MLP); 2 H, 2 M, Mendoza, 26-XI-1906, 3-XII-1907, 25-XII-1907, P. Jörgensen (MLP); 1 F, Agrelo, 23-II-1966, L. Stange (IFML); $1 \mathrm{M}, 16$ km W Carrizal, 6-I-1990, A. Roig Alsina (MACN). Entre Ríos: 1 H, Paraná, Jan., Burmeister (MACN); 2 F, Pronunciamiento, Zelich col. (MACN); $1 \mathrm{~F}$, Primero de Mayo, 2-XII-1955 (MLP); $3 \mathrm{~F}$, Diamante, 29-III-1918, 1-IV-1918, A. Frers (MACN). Santa Fe: 1 F, 1 M, 11942 (MACN). Buenos Aires: 2 M, V. Elordi, 15-XI-1942 (MLP); 1 M, Hurlingham, 24-III-1945, A. Ogloblin (MLP); 1 F, San Pedro, II-1920, A. Frers (MACN). La Pampa: 2 F, Toay, Estancia Anquiloo, 14-I-2001, J.P. Torretta (MACN). Río Negro: 1 F, 1 M, Río Colorado, III1958, A. Ogloblin (MLP).

\section{ACKNOWLEDGMENTS}

This study was funded by the Consejo Nacional de Investigaciones Científicas y Técnicas, Argentina, PIP 5755.

\section{BIBLIOGRAPHY}

Alexander, B. 1991. Nomada phylogeny reconsidered (Hymenoptera, Anthophoridae). J. Nat. Hist. 25: 315-330.

- 1994. Species-groups and cladistic analysis of the cleptoparasitic bee genus Nomada (Hymenoptera: Apoidea). Univ. Kansas Sci. Bull. 55: 175-238.

Alexander, B. \& M. Schwarz. 1994. A catalog of the species of Nomada (Hymenoptera: Apoidea) of the world. Univ. Kansas Sci. Bull. 55: 239-270.

Brèthes, J. 1909. Hymenoptera Paraguayensis. An. Mus. Nac. Buenos Aires 19: 225256.

Cockerell, T. D. A. 1911. Bees in the collection of the United States National Museum. I. Proc. U. S. Nat. Mus. 39: 635-658.

- 1916. Some Neotropical parasitic bees. Entomol. News 27: 208-210.

- 1917. Descriptions and records of bees. 76. Ann. Mag. Nat. Hist. (8) 20: 235-241.

- 1949. Bees from Central America, principally Honduras. Proc. U. S. Nat. Mus. 98: 429-490.

Dalla Torre, C.G. de. 1896. Catalogus Hymenopterorum..., X. Lipsiae, viii + $643 \mathrm{pp}$.

Ducke, A. 1908. Contributions à la connaissance des Hyménoptères des deux Ameriques. Rev. d'Ent., Caen 27: 28-55.

- 1910. Contribution à la connaissance de la faune hyménoptérologique du Nord Est du Brésil. III Hyménoptères récoltés dans l'Etat de Ceara en 1909 et supplements aux deux listes anterieures. Rev. d'Ent., Caen 28: 78-109. 
- 1912. Die natürlichen Bienengenera Südamerikas. Zool. Jahrb., Abt. Syst., 34(1): 51116.

Friese, H. 1908. Die Apidae (Blumenwespen) von Argentina nach der Reisenergebnissen der Herren A.C. Jensen Haarup und P. Jörgensen in den Jahren 1904 1907. Flora og Fauna 1908: 1-111.

- 1916. Zur Bienenfauna von Costa Rica (Hym.). Stett. Ent. Zeitg. 77: 287-350.

Holmberg, E. L. 1886. Sobre ápidos nómadas de la República Argentina. An. Soc. Cientif. Argentina, 22: 231 240, 272-286.

Jörgensen, P. 1909. Beobachtungen über Blumenbesuch, Biologie, Verbreitung usw. der Bienen von Mendoza (Hym.). Deutsch. Ent. Zeitschr. 1909: 211227.

- 1912a. Revision der Apiden der Provinz Mendoza, Republica Argentina (Hym.). Zool. Jahrb., Abt. Syst. 32(2): 89-162.

- 1912b. Los crisididos y los himenopteros aculeados de la provincia de Mendoza. An. Mus. Nac. Buenos Aires 22: 267-338.

Michener, C.D. 1954. Bees of Panamá. Bull. Am. Mus. Nat. Hist. 104: 1-175.

- 2000. The bees of the World. The Johns Hopkins University Press, Baltimore and London, xiv + 913 pp.

- 2007. The bees of the World. Second edition. The Johns Hopkins University Press, Baltimore and London, $992 \mathrm{pp}$.

Moure, J. S. \& G. A. R. Melo. 2007. Nomadini. In: Moure, J.S., Urban, D. \& Melo, G.A.R. (Eds.), Cata- logue of bees (Hymenoptera, Apoidea) in the Neotropical Region. Sociedade Brasileira de Entomologia, Curitiba, pp. 757-872.

Roig Alsina, A. 1991. Cladistic analysis of the Nomadinae s. str. with description of a new genus (Hymenoptera: Anthophoridae). J. Kansas Entomol. Soc., 64 (1): 23-37.

Rozen, J. G, Jr. 1997. New taxa of brachynomadine bees (Apidae: Nomadinae). Am. Mus. Novitates 3200: 126.

Sandhouse, G. A. 1943. The type species of the genera and subgenera of bees. Proc. U.S. Nat. Mus. 92: 519619.

Schrottky, C. 1903. Enumération des Hyménoptères connus jusq'ici de la R. Argentine, de l' Uruguay et du Paraguay. An. Soc. Cientif. Argentina 55: 176186.

1913. La distribución geográfica de los himenópteros argentinos. An. Soc. Cientif. Argentina 75: 225286.

Schwarz, M. \& F. Gusenleitner. 2004. Beitrag z ur Klärung und Kenntnis parasitärer Bienen der Gattungen Coelioxys und Nomada (Hymenoptera, Apidae). Linzer biol. Beitr. 36: 1413-1485.

Silveira, F., G. A. R. Melo \& E. A. B. Almeida. 2002. Abelhas brasileiras. Sistemática e identificaçao. Belo Horizonte, 253 pp.

Snelling, R. R. 1986. Contributions toward a revision of the New World nomadine bees. A partitioning of the genus Nomada (Hymenoptera: Anthopho-ridae). Cont. Sci., Los Angeles Co. Mus. 376: 132 . 